\title{
HGT
}

\section{Systemic Adeno-Associated Virus-Mediated Gene Therapy Prevents the Multiorgan Disorders Associated with Aldehyde Dehydrogenase 2 Deficiency and Chronic Ethanol Ingestion}

\author{
Yuki Matsumura, ${ }^{1} \mathrm{Na} \mathrm{Li}{ }^{2}$ Hanan Alwaseem, ${ }^{3}$ Odelya E. Pagovich, ${ }^{1}$ Ronald G. Crystal, ${ }^{1, *, \dagger}$ \\ Matthew B. Greenblatt, ${ }^{2,4, \dagger}$ and Katie M. Stiles ${ }^{1, \dagger}$ \\ ${ }^{1}$ Department of Genetic Medicine and ${ }^{2}$ Pathology and Laboratory Medicine, Weill Cornell Medical College, New York, New York; ${ }^{3}$ Proteomics Resource Center, \\ The Rockefeller University, New York, New York; ${ }^{4}$ Research Division, Hospital for Special Surgery, New York, New York. \\ ${ }^{\dagger}$ These authors contributed equally as senior authors.
}

\begin{abstract}
Aldehyde dehydrogenase type 2 (ALDH2), a key enzyme in ethanol metabolism, processes toxic acetaldehyde to nontoxic acetate. ALDH2 deficiency affects $8 \%$ of the world population and 35-45\% of East Asians. The $A L D H 2 * 2$ allele common genetic variant has a glutamic acid-to-lysine substitution at position 487 (E487K) that reduces the oxidizing ability of the enzyme resulting in systemic accumulation of acetaldehyde with ethanol ingestion. With chronic ethanol ingestion, mutations in ALDH2 are associated with a variety of hematological, neurological, and dermatological abnormalities, and an increased risk for esophageal cancer and osteoporosis. Based on our prior studies demonstrating that a one-time administration of an adeno-associated virus (AAV) serotype rh.10 gene transfer vector expressing the human $A L D H 2$ cDNA (AAVrh.10hALDH2) prevents the acute effects of ethanol administration (the "Asian flush syndrome"), we hypothesized that AAVrh.10hALDH2 would also prevent the chronic disorders associated with ALDH2 deficiency and chronic ethanol ingestion. To assess this hypothesis, AAVrh.10hALDH2 (10 11 genome copies $)$ was

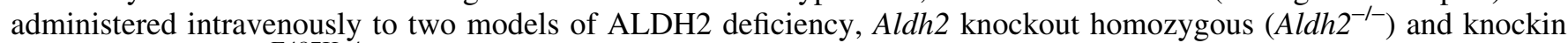
homozygous $\left(A l d h 2^{\mathrm{E} 487 \mathrm{~K}+/+}\right)$ mice $(n=10$ per group). Four weeks after vector administration, mice were given drinking water with $10-15 \%$ ethanol for 12 weeks. Strikingly, compared with nonethanol drinking littermates, AAVrh.10hALDH2 administration prevented chronic ethanol-induced serum acetaldehyde accumulation and elevated liver malondialdehyde levels, loss of body weight, reduced hemoglobin levels, reduced performance in locomotor activity tests, accumulation of esophageal DNA damage and DNA adducts, and development of osteopenia. AAVrh.10hALDH2 should be considered as a preventative therapy for the increased risk of chronic disorders associated with ALDH2 deficiency and chronic alcohol exposure.
\end{abstract}

Keywords: ALDH2, esophageal cancer, osteoporosis, AAV gene therapy

\section{INTRODUCTION}

ONE OF THE MOST common hereditary disorders, aldehyde dehydrogenase type 2 (ALDH2) deficiency, affects 560 million people, $\sim 8 \%$ of the world population. ${ }^{1,2}$ Individuals of East Asian descent have the highest prevalence (35-45\%). ${ }^{2,3}$ ALDH2 belongs to a superfamily of enzymes that metabolize endogenous and exogenous aldehydes. ${ }^{4}$ The autosomal gene codes for an enzyme localized to mitochondria. ALDH2 is ubiquitously expressed at low levels in all tissues, but is most abundant in the liver, the primary organ of ethanol metabolism. ${ }^{5,6} \mathrm{ALDH} 2$ is the second enzyme in the ethanol metabolism pathway and converts acetaldehyde, a toxic intermediate, to acetate (Supplementary Fig. S1). ${ }^{7}$ Significant accumulation of serum acetaldehyde after ethanol ingestion results from mutations in ALDH2 that reduce the oxidizing ability of the enzyme. ${ }^{3,8,9}$ The ALDH2 enzyme is a tetramer and the mutant protein functions as a dominant negative..$^{10,11}$ Heterozygotes have $<50 \%$ ALDH 2 enzymatic activity and homozygotes $<4 \% .^{12,13}$

The most common mutation is a glutamic acid-to-lysine substitution at position 487 (E487K), commonly referred to as the $A L D H 2 * 2$ allele. ${ }^{3,14}$ With acute ethanol ingestion, mutations in ALDH2 are responsible for the "Asian flush

${ }^{*}$ Correspondence: Dr. Ronald G. Crystal, Department of Genetic Medicine, Weill Cornell Medical College, 1300 York Avenue, Box 164, New York, NY 10065. E-mail. geneticmedicine@med.cornell.edu 
syndrome," with erythema, nausea, headaches, and general systemic discomfort. ${ }^{3,13,15}$ With chronic ethanol ingestion, ALDH2 mutations are associated with a number of serious medical conditions, including hematological, dermatological, and neurological abnormalities, a markedly increased risk for cancers of the oral cavity, pharynx, larynx, and esophagus, ${ }^{23,16,17}$ and osteoporosis. ${ }^{18-24}$

There are two mouse models of ALDH2 deficiency that mimic many of the molecular and clinical phenotypes of humans carrying the $A L D H 2 * 2$ allele. ${ }^{12,25}$ In these mouse models, chronic administration of ethanol or acetaldehyde induces the chronic disorders associated with ALDH2 deficiency. ${ }^{9,26,27}$ The Aldh2 knockout mouse $\left(A l d h 2^{-/-}\right.$) does not express detectable ALDH2 protein or enzymatic activity. ${ }^{12}$ After ethanol administration, Aldh $2^{-/-}$mice have significantly higher levels of serum acetaldehyde than wildtype mice, and chronic exposure to ethanol results in weight loss and increased mortality. ${ }^{28,29}$ The Aldh2 E487K knockin mouse $\left(A l d h 2^{\mathrm{E} 487 \mathrm{~K}+/+}\right)$ has the lysine 487 mutation from the human $A L D H 2 * 2$ allele. ${ }^{25}$ These mice have reduced ALDH2 enzymatic activity and, when challenged with ethanol, have high serum acetaldehyde levels and exhibit increased ethanol-related behavioral abnormalities.

We have previously demonstrated that the acute effects of ethanol in these murine models of ALDH2 deficiency (the mouse equivalent of the "Asian flush syndrome") can be corrected by systemic liver-directed serotype rh.10 adenoassociated virus (AAVrh.10hALDH2)-mediated delivery of the normal human $A L D H 2$ coding sequence. ${ }^{30}$ In this study, we have extended these observations in these two murine models of ALDH2 deficiency to assess whether this therapy will prevent the diseases associated with chronic ethanol ingestion. Strikingly, the therapy prevents chronic alcoholmediated body weight loss, anemia, poor locomotion, skin pigmentation, elevated serum acetaldehyde, and liver malondialdehyde (MDA) levels. Importantly, AAVrh.10hALDH2 gene therapy also prevented esophageal DNA damage and adduct accumulation, precursors to the development of esophageal cancer, and the development of osteopenia, the murine equivalent of human osteoporosis.

\section{METHODS}

\section{Mouse models of ALDH2 deficiency}

The ALDH2 knockout homozygous (Aldh2 ${ }^{--}$) mice, backcrossed with C57Bl/6 mice, were obtained from the Department of Environmental Health, University of Occupational and Environmental Health (Kitakyushu, Japan). ${ }^{12}$ The Aldh2 E487K knockin homozygous mice $\left(\right.$ Aldh $\left.2^{\mathrm{E} 487 \mathrm{~K}+/+}\right)$, a knockin mouse model of ALDH2 deficiency expressing mouse ALDH2 with the inactivating point mutation from the human $A L D H 2 * 2$ gene, were obtained from the Department of Chemical and Systems Biology, Stanford University School of Medicine (Stanford, CA). ${ }^{25}$ All mice were housed in microisolator cages and all food and water were autoclaved. Mice were bred as pairs (one female with one male) or trios (two females with one male). To generate homozygous mice, mice were bred as heterozygous pairs with genotyping of pups at 3 weeks of age by PCR (Transnetyx, Cordova, TN). The primers for Aldh $2^{-/-}$genotyping were forward-5'-GGACGTAGACAA GGCAGTGAAG, reverse-5'-CCCTACCCGGTAGAAT TCGATATCA and those for Aldh2 ${ }^{\mathrm{E} 487 \mathrm{~K}+/+}$ genotyping were forward-5'-GGAGCTGGGCGAGTATGG, reverse$5^{\prime}$-GAGTCTGAAGGCTGTGTACGTA ${ }^{12,25}$ ). All experiments conformed to the relevant regulatory standards and were approved by the Institutional Animal Care and Use Committee of Weill Cornell Medical College. Because alcohol consumption in the East Asian population is dominated by males ${ }^{31}$ and because female mice respond to adenoassociated virus (AAV) vector with expression as much as 1 $\log$ less than males, ${ }^{32}$ we utilized male mice for all studies.

\section{AAV vectors}

The AAVrh.10hALDH2 vector comprises the nonhuman primate-derived rh.10 capsid and an expression cassette including the $5^{\prime}$ and $3^{\prime}$ AAV2 inverted terminal repeats, the cytomegalovirus enhancer, chicken- $\beta$-actin promoter and intron, and rabbit $\beta$ globin splice acceptor (CAG promoter), the human $A L D H 2$ coding sequence with a hemagglutinin (HA) tag, and rabbit $\beta$-globin polyadenylation signal (Supplementary Fig. S2) ${ }^{30}$ The HA tag was used for differentiating between human and mouse ALDH2 proteins because the mouse and human amino acid sequences are $96 \%$ homologous (NCBI Homologene: https://www.ncbi.nlm.nih.gov/homologene/55480).

The vector was produced using human embryonic kidney $293 \mathrm{~T}$ cells as described previously. ${ }^{32}$ In brief, the pAAV-CAG-hALDH2 expression plasmid $(600 \mu \mathrm{g})$ and the AAVrh.10 packaging-Ad helper hybrid plasmid pPAKMArh.10 $(1,200 \mu \mathrm{g})$ were cotransfected into 293T cells using polyethylenimine (PEI) transfection reagent (Polysciences, Warrington, PA). At $72 \mathrm{~h}$ post-transfection, cells were harvested and lysate was prepared using five cycles of freeze-thaw. The cell lysate containing the virus was clarified by centrifugation at $2675 \times \mathrm{g}$ for $15 \mathrm{~min}$. The AAVrh.10hALDH2 vector was purified from the crude viral lysate by iodixanol gradient and HiTrap Q High Performance anion exchange chromatography (GE Healthcare, Piscataway, NJ), concentrated using a BioMax $100 \mathrm{~K}$ membrane concentrator (Millipore, Billerica, MA) and stored in phosphate-buffered saline, $\mathrm{pH} 7.4$ at $-80^{\circ} \mathrm{C}$.

Vector genome titers were determined by TaqMan qPCR using a CAG-specific primer-probe set (forward primer: 5'-GTCAATGGGTGGAGTATTTACGG, reverse primer: 5'-AGGTCATGTACTGGGCATAATGC) (Applied Biosystems, Foster City, CA). The purified AAVrh. $10 \mathrm{hALDH} 2$ vector was digested with proteinase $\mathrm{K}$ in the presence of $0.5 \%$ sodium dodecyl sulfate (SDS) plus $25 \mathrm{mM}$ ethylenediaminetetraacetate (EDTA) at $70^{\circ} \mathrm{C}$ for 
$1 \mathrm{~h}$ followed by inactivation of the protease at $95^{\circ} \mathrm{C}$ for $15 \mathrm{~min}$. The vector was then used as a template for TaqMan analysis using a pAAV-CAG-hALDH2 plasmid DNA standard of known copy number to generate a standard curve. The AAVrh.10control vector expresses an irrelevant transgene. ${ }^{33}$

\section{Overview of efficacy studies with AAVrh.10hALDH2}

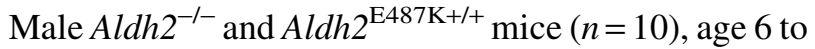
10 weeks, were administered intravenously in $100 \mu \mathrm{L}$ a one-time dose of AAVrh.10hALDH2 $\left(10^{11} \mathrm{gc}\right)$ or AAVrh .10 control $\left(10^{11} \mathrm{gc}\right)$. C57Bl/6 mice were administered phosphate-buffered saline (PBS). Four weeks later, mice were given water or ethanol in water for 12 weeks $(10 \%$ ethanol in water for the first 6 weeks and $15 \%$ ethanol in water for the second 6 weeks) ad libitum in the drinking water. Water or ethanol intake was assessed every week. Mice were evaluated for a variety of chronic disease phenotypes, including body weight, hemoglobin level, muscular coordination and strength (rotarod test), and skin pigmentation every 3 weeks. After 12 weeks ethanol ingestion, mice were sacrificed. Liver hALDH2 mRNA was evaluated by Taqman RT-qPCR and hALDH2 protein by Western analysis and immunohistochemistry. ALDH2 enzymatic activity and MDA levels in liver were quantified using commercially available assay kits. Serum acetaldehyde levels were measured by liquid chromatography/mass spectrometry (LC/MS) after derivatization. DNA damage on esophageal epithelium was evaluated by $\gamma \mathrm{H} 2 \mathrm{AX}$ immunohistochemistry. Esophagus DNA adducts were assessed by measuring $\mathrm{N}^{2}$-ethyl-2'-deoxyguanosine $\left(\mathrm{N}^{2}\right.$ et-dG) by LC/MS. Osteopenia was assessed by microcomputed tomography $(\mu \mathrm{CT})$ and histology.

\section{Assessment of water or ethanol intake}

To quantify water or ethanol intake, a test was performed with mice $(n=14)$ subgrouped into two sets of one, two, and four mice separated into different cages. Bottles (Techniplast, West Chester, PA) were filled with $500 \mathrm{~mL}$ water or ethanol in water $(10 \%$ ethanol in water for the first 6 weeks and $15 \%$ ethanol in water for the second 6 weeks) and weighed before beginning the challenge. Each week, bottles were weighed, refilled to $500 \mathrm{~mL}$, and placed back in the cage. Two control cages with the same type of bottle containing $500 \mathrm{~mL}$ water or ethanol were also set up as controls for evaporation and loss of liquid during cage movement. Water or ethanol intake for each cage of mice was calculated by the weight of the bottle in the cage minus weight of the water bottle from the control cage.

\section{ALDH2 expression in liver}

Human $A L D H 2$ mRNA levels in the liver were assessed by TaqMan RT-qPCR using FAM dye labeled $\mathrm{h} A L D H 2$ specific primer-probe sets (Assay ID; Hs01007998_ml) and murine 18S-specific primer-probe sets (Life Technologies, Waltham, MA). ALDH2 protein was quantified by Western analysis with an antibody against the HA tag (Sigma-Aldrich, St. Louis, MO). Paraformaldehyde-fixed livers were embedded in paraffin and cut into $5 \mu \mathrm{m}$ sections. Vector-derived hALDH2 expression in the liver was detected by an anti-HA antibody (Histowiz, Brooklyn, NY). After sectioning, anti-HA immunohistochemical staining, and counterstaining with hematoxylin, digital images of liver cross-sections were acquired using a $20 \times$ objective. The enzymatic activity of ALDH 2 in liver was analyzed using the colorimetric mitochondrial aldehyde dehydrogenase (ALDH2) activity assay kit (ab115348; Abcam, Cambridge, MA) according to the manufacturer's protocol using $200 \mu \mathrm{g}$ of total protein from liver homogenate. C57B1/6 mice administered PBS were used as controls.

\section{Acetaldehyde}

Acetaldehyde measurements were performed at the Proteomics Resource Center, Rockefeller University ${ }^{9,34}$ $(n=5 \mathrm{mice} /$ group). Acetaldehyde levels were determined through derivatization with dinitrophenylhydrazine (DNPH) using butyraldehyde-DNPH (Accustandard, New Haven, CT) as an internal standard. Blood $(120 \mu \mathrm{L})$ was deproteinized by addition of an equal volume of cold acetonitrile (ACN) and centrifuged for $30 \mathrm{~min}$ at $3,500 \mathrm{~g}$ at $4^{\circ} \mathrm{C}$. Supernatant $(48 \mu \mathrm{L})$ was mixed with $2 \mu \mathrm{L}$ of $10 \mathrm{mM}$ ${ }^{13} \mathrm{C}$-acetaldehyde. Then, $15 \mu \mathrm{L}$ of $16 \mathrm{mM}$ DNPH in ACN and $5 \mu \mathrm{L}$ of $1 \mathrm{M}$ citric acid ( $\mathrm{pH} 4.0$ ) were added. After incubation at $25^{\circ} \mathrm{C}$ for $30 \mathrm{~min}$, the reaction was quenched with $60 \mu \mathrm{L}$ of $0.1 \%$ formic acid in water, and samples were kept in $-80^{\circ} \mathrm{C}$ until analysis. Before LC/MS, $49 \mu \mathrm{L}$ of sample was spiked with $1 \mu \mathrm{L}$ of butyraldehyde-DNPH standard for a final concentration of $20 \mathrm{pm} / \mu \mathrm{L}$. Acetaldehyde-DNPH (Accustandard, New Haven, CT) was used as an external calibrant to verify retention time. Samples were analyzed on a Dionex U-3000 HPLC system coupled to a TSQ Vantage triple-quad mass spectrometer (Thermo Fisher Scientific, Waltham, MA) equipped with a heated electrospray ionization source (HESI). Chromatographic separation was performed using a Thermo Acclaim $120 \mathrm{C} 8(2.1 \times 150 \mathrm{~mm}, 3 \mu \mathrm{m}$ particle size $)$ column at a flow rate of $200 \mu \mathrm{L} / \mathrm{min}$, using $0.1 \%$ LC-grade formic acid (Pierce, Thermo Fisher Scientific) in water as buffer A and $100 \%$ methanol (Optima, Fisher Scientific, Hampton, $\mathrm{NH})$ as buffer B. The gradient was the following: $5 \%$ buffer B (0-2 min), increased to $60 \%$ buffer B (2-10 min), increased to $80 \%$ buffer B (10-20 min), increased to $100 \%$ buffer B (20-21 min), held at 100\% buffer B (21-26 min), returned to $50 \%$ buffer B $(26-26.1 \mathrm{~min})$ and held at $50 \%$ buffer B (26.1-30 min) for re-equilibration of the column. The mass spectrometer was operated with the following parameters; negative ion polarity; spray voltage, $3500 \mathrm{~V}$; ion transfer capillary temperature, $350^{\circ} \mathrm{C}$; source 
temperature, $37^{\circ} \mathrm{C}$; sheath gas, 35 (arbitrary units); auxiliary gas, 10 (arbitrary units); collision gas, argon. The S-Lens voltage (S-lens) and collision energy (CE) were manually optimized for each multiple reaction monitoring (MRM) transition. The MRM transitions monitored were: Acetaldehyde-DNPH, $m / z, 223 \rightarrow 122(\mathrm{CE}=21, \mathrm{~S}$-Lens $=$ $65), 223 \rightarrow 163(\mathrm{CE}=13$, S-Lens $=65), 223 \rightarrow 181(\mathrm{CE}=$ 18 , S-Lens $=65) ;{ }^{13} \mathrm{C}$-Acetaldehyde-DNPH, $\mathrm{m} / \mathrm{z}, 225 \rightarrow$ $122(\mathrm{CE}=21, \mathrm{~S}$-Lens $=65), 225 \rightarrow 163(\mathrm{CE}=13, \mathrm{~S}$-Lens $=$ $65), 225 \rightarrow 181(\mathrm{CE}=18$, S-Lens $=65)$; Butyraldehyde$\mathrm{DNPH}, m / z, 251 \rightarrow 122(\mathrm{CE}=27$, S-Lens $=70), 251 \rightarrow 152$ $(\mathrm{CE}=19, \mathrm{~S}$-Lens $=70), 251 \rightarrow 163(\mathrm{CE}=13, \mathrm{~S}$-Lens $=70)$. Quantitation was performed using a known amount of

${ }^{13} \mathrm{C}$-acetaldehyde standard in the sample and an external calibration curve of acetaldehyde-DNPH prepared in parallel. Rate constants of acetaldehyde consumption were determined by fitting time-concentration values to a firstorder decay model. Butyaldehyde-DNPH was used to evaluate instrument performance.

\section{Malondialdehyde}

MDA in liver homogenate was assayed by TBARS Assay Kit (Cayman, MI) according to a modified manufacturer's protocol. In brief, the mixture of $25 \mu \mathrm{L}$ liver homogenate, $25 \mu \mathrm{L} \mathrm{SDS}$, and $1 \mathrm{~mL}$ color reagent was boiled at $99^{\circ} \mathrm{C}$ for $1 \mathrm{~h}$. After cooling down on ice for $10 \mathrm{~min}$, the sample was centrifuged at 1,600 $\mathrm{g}$ for $10 \mathrm{~min}$ and the absorbance was read at $540 \mathrm{~nm}$ by a spectrophotometer. MDA concentration was normalized by the amount of total protein determined by Pierce ${ }^{\mathrm{TM}}$ BCA Protein Assay Kit (Thermo Scientific).

\section{Assessment of body weight, hemoglobin, locomotion, and skin pigmentation}

To assess the effects of chronic ethanol challenge on total body mass, mice were weighed at pre-ethanol, 3, 6, 9, and 12 weeks time points.

Hemoglobin levels were determined in blood collected in EDTA tubes from the tail vein at pre-ethanol, 3, 6, 9, and 12 weeks time points and were automatically counted using the ADVIA 120 Hematology System (Siemens Healthineers, Erlangen, Germany).

The rotarod behavior test was used to evaluate mouse strength and coordination every 3 weeks during ethanol challenge. An automated four-lane rotarod unit (AccuScan Instruments, Columbus, $\mathrm{OH}$ ) was used to evaluate locomotor activity. The apparatus has $7 \mathrm{~cm}$ diameter drums with grooves to improve grip. Drums were rotated at a fixed speed of 2 rotations/min (rpm) for the first $20 \mathrm{~s}$, accelerated up to $30 \mathrm{rpm}$ in the next $100 \mathrm{~s}$, and then up to $60 \mathrm{rpm}$ in the last $60 \mathrm{~s}$. The time and rpm when mouse fell from or failed to walk on a drum were recorded. Failure to walk was defined as a mouse that did not fall from the drum, but clung in one position and went around twice. Tests were performed twice at each time point and the average rpm was calculated.
To assess skin pigmentation from chronic ethanol ingestion, pictures were taken of exposed ear, genitals, tail, and sole skin of each mouse. For analysis, darkness of the paw sole was quantified with ImageJ. All sole areas were traced and intensity of every dot in the traced area was measured as mean red-green-blue (RGB) intensity. Positive pigmentation was quantified as an intensity with mean RGB intensity of 90 or less after normalization to the mean RGB intensity of white background.

\section{DNA damage and adducts}

DNA damage was assessed by immunohistochemistry for $\gamma \mathrm{H} 2 \mathrm{AX} . \gamma \mathrm{H} 2 \mathrm{AX}$ was stained with an antibody to phosphohistone H2A.X (Ser 139) (clone: 20E3, 1:100, Cell Signaling Technology, MA), and the number of $\gamma \mathrm{H} 2 \mathrm{AX}$-positive cells and total epithelial cells on the basal membrane of the esophagus were counted using a $40 \times$ objective. Measurement of the DNA adduct $\mathrm{N}^{2}$-et-dG in esophagus DNA was performed at the Proteomics Resource Center, Rockefeller University for $n=5$ mice per group. DNA was extracted from a whole mouse esophagus using the QIAGEN (Germantown, MD) DNAeasy Blood \& Tissue Kit, according to the manufacturer's protocol except with the addition of sodium cyanoborohydride $\left(\mathrm{NaBH}_{3} \mathrm{CN}\right)$ to each reagent of the kit ( $150 \mathrm{mM}$ to cell lysis buffer and $100 \mathrm{mM}$ to other reagents). Extracted DNA was dissolved in $60 \mu \mathrm{L}$ of $10 \mathrm{mM}$ Tris- $\mathrm{HCl} / 5 \mathrm{mM}$ EDTA buffer ( $\mathrm{pH} 7.5)$, and the amount of DNA was measured by Nanodrop. Extracted DNA was mixed with $1.2 \mu \mathrm{L}$ of $1 \mathrm{M}$ citrate buffer (pH 6.0), $0.8 \mu \mathrm{L}$ of $750 \mathrm{mM} \mathrm{CaCl}_{2}$, $45 \mathrm{U}$ micrococcal nuclease (Worthington Biochemical Corporation, Lakewood, NJ), $0.15 \mathrm{U}$ spleen phosphodiesterase (Worthington Biochemical Corporation), $4.8 \mu \mathrm{L}$ of $8 \mathrm{M} \mathrm{NaBH}_{3} \mathrm{CN}$, and $1 \mu \mathrm{L}$ of $5 \mathrm{pm} / \mu \mathrm{L}$ internal standard. The mixture was incubated at $37^{\circ} \mathrm{C}$ for $3 \mathrm{~h}$, and then $2.5 \mu \mathrm{L}$ of $2 \mathrm{M}$ Tris- $\mathrm{HCl}(\mathrm{pH} 8.5), 2 \mu \mathrm{L}$ of $45 \mathrm{mM}$ $\mathrm{ZnSO}_{4}, 6 \mathrm{U}$ alkaline phosphatase (Sigma-Aldrich), $1 \mu \mathrm{L}$ of $8 \mathrm{M} \mathrm{NaBH}_{3} \mathrm{CN}$, and $1.5 \mu \mathrm{L}$ distilled water were added. After incubation at $37^{\circ} \mathrm{C}$ for $3 \mathrm{~h}$, nucleosides were extracted twice with $600 \mu \mathrm{L}$ of chilled methanol and the combined supernatant was evaporated to dryness. The dried samples were resuspended in $100 \mu \mathrm{L}$ LC/MS grade water (Optima ${ }^{\mathrm{TM}}$; Fisher Scientific), sonicated for $10 \mathrm{~s}$, centrifuged at $4^{\circ} \mathrm{C}$ for $10 \mathrm{~min}$, and supernatant was subjected to liquid chromatography tandem mass spectrometry (LC-MS/MS) analyses.

LC-MS/MS analyses were performed using a Vantage TSQ triple-stage quadrupole mass spectrometer (Thermo Fisher Scientific) equipped with a heated electrospray ionization source. The mass spectrometer was operated with the following parameters: positive ion polarity; spray voltage, $3,500 \mathrm{~V}$; ion transfer capillary temperature, $300^{\circ} \mathrm{C}$; source temperature, $250^{\circ} \mathrm{C}$; sheath gas, 30 (arbitrary units); auxiliary gas, 10 (arbitrary units); collision gas, argon; and dwell time, $200 \mathrm{~ms}$. The S-Lens voltage (S-lens) and collision energy (CE) were manually optimized for each MRM transition. The MRM transitions monitored 
were deoxyguanosine $(\mathrm{dG}), \mathrm{m} / z, 268 \rightarrow 152(\mathrm{CE}=12$, S-lens $=50) ;\left[{ }^{15} \mathrm{~N}_{5}\right]-\mathrm{N} 2$-et-dG, $\mathrm{m} / z \quad 301 \rightarrow 185(\mathrm{CE}=14$, S-lens =57); and $\mathrm{N}^{2}$-et-dG, $\mathrm{m} / \mathrm{z}, 296 \rightarrow 180(\mathrm{CE}=12$, Slens $=60$ ). Chromatographic separation was performed on a Dionex Ultimate 3000 HPLC equipped with a Thermo Hypersil Gold aQ column $(2.1 \mathrm{~mm} \times 150 \mathrm{~mm} \times 3$ $\mu \mathrm{m}$ particle size). Column temperature was maintained at $36^{\circ} \mathrm{C}$ and the autosampler was set to $4^{\circ} \mathrm{C}$. Mobile phase A consisted of $0.1 \%$ LC-grade formic acid (Pierce; Thermo Scientific) in water and mobile phase B consisted of $0.1 \%$ LC-grade formic acid in ACN. Separation was achieved using the following gradient (flow rate set at $0.4 \mathrm{~mL} / \mathrm{min}$ ): $0 \%$ B (0-6 min), 1\% B (6-7.65 min), 6\% B (7.65$9.35 \mathrm{~min})$, held at $6 \% \mathrm{~B}(9.35-10 \mathrm{~min})$, increased to $50 \%$ B (10-12 min), 75\% B (12-14 min), held at $75 \%$ B (14-17 min), returning to $0 \% \mathrm{~B}(17-17.5 \mathrm{~min})$, and reequilibrating $(17.5-30 \mathrm{~min})$. The injection volume was $1-3 \mu \mathrm{L}$ with $\geq 2$ technical replicates per biological replicate. The amount of $\mathrm{N}^{2}$-et-dG in each DNA sample was determined from the ratio of the peak area of $\mathrm{N}^{2}$-et-dG relative to the internal standard $\left[{ }^{15} \mathrm{~N}_{5}\right] \mathrm{N}^{2}$-et-dG and by using a calibration curve $\left(0.6-2,500 \mathrm{fmol} / \mu \mathrm{L}, r^{2} \geq 0.98\right)$. Owing to the high concentrations of $\mathrm{dG}$ in each DNA sample, the original resuspension stock was further diluted 100 -fold followed by injection of $0.5-1 \mu \mathrm{L}$ of this mixture onto the column. The amount of dG was then determined using a calibration curve $\left(20-1,250 \mathrm{fmol} / \mu \mathrm{L}, r^{2} \geq 0.97\right)$.

\section{$\mu \mathrm{CT}$ and histological analysis of femurs}

Femurs fixed in 4\% paraformaldehyde then stored in 70\% ethanol were scanned using a high-resolution Scanco $\mu \mathrm{CT} 35$ (Scanco Medical AG, Bruttisellen, Switzerland). Specimens were scanned with an isotropic voxel size of $7 \mu \mathrm{m}$. For analysis of femoral bone mass, a region of trabecular bone $2.1 \mathrm{~mm}$ wide was contoured, starting $280 \mu \mathrm{m}$ from the proximal end of the distal femoral growth plate. Femoral trabecular bone was thresholded at 211 permille and femoral cortical bone was thresholded at 350 permille. A Gaussian noise filter optimized for murine bone was applied to reduce noise in the thresholded two-dimensional (2D) image. Three-dimensional reconstructions were created by stacking the thresholded 2D images from the contoured regions.

For histological analysis, femurs were decalcified with 0.5 M EDTA (pH 8.0) and embedded in paraffin. Sections were deparaffinized and stained with hematoxylin and eosin. Metaphysis was defined as the area within $2 \mathrm{~mm}$ from the bottom of growth plate. Areas of metaphysis for each trabecular bone were traced and quantified by ImageJ. The ratio of trabecular bone in metaphysis was calculated by dividing the sum area of each trabecular bone in metaphysis by total area of metaphysis.

\section{Statistical analysis}

All data are presented as means \pm standard error of the mean (SEM) unless otherwise stated; the " $n$ " value for each group is stated in the figure or figure legend. Differences between groups were analyzed using an unpaired two-tailed Student's $t$-test. The behavior score and body temperature after ethanol exposure were also correlated with acetaldehyde levels. These correlations were evaluated using the correlation test for paired samples. $r^{2}$ values $>0.8$ indicate a strong relationship between the test groups. $p$-Values $<0.05$ were considered significant for all comparisons.

\section{RESULTS}

\section{AAVrh.10hALDH2-mediated expression of $\mathrm{h} A L D H 2$}

Aldh2 $2^{-/-}$and Aldh2 $2^{\mathrm{E} 487 \mathrm{~K}+/+}$ mice were treated with AAVrh.10hALDH2 (Supplementary Fig. S2) or AAVrh .10 control $\left(10^{11} \mathrm{gc}\right)$ by intravenous administration. Sixteen weeks later, $\mathrm{h} A L D H 2$ mRNA, protein levels, and ALDH2 enzymatic activity in liver were analyzed.

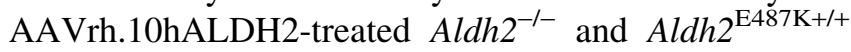
mice had significantly higher $\mathrm{h} A L D H 2$ mRNA expression in liver than AAVrh.10control-treated mice (Aldh2 $2^{-1}$, $p<10^{-4}$; Aldh2 $2^{\mathrm{E} 487 \mathrm{~K}+/+}, p<10^{-5}$; Fig. 1A). Western analysis revealed liver hALDH2 protein expression in AAVrh.10hALDH2-treated Aldh2 $2^{-/-}$and Aldh2 $2^{\mathrm{E} 487 \mathrm{~K}+/+}$

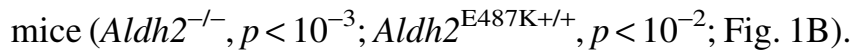
Liver immunohistochemical staining of AAVrh

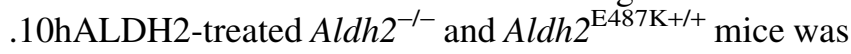
consistent with the Western analysis. Liver hALDH2 positive cells were found mainly around hepatic and portal veins in AAVrh.10hALDH2-treated mice, whereas no positive cells were observed in AAVrh.10control-treated mice (Fig. 1C). In addition, AAVrh.10control-treated mice had undetectable levels of ALDH2 liver enzyme activity, whereas AAVrh.10hALDH2-treated mice showed high levels of enzymatic activity $\left(A l d h 2^{-/-}, p<10^{-4}\right.$; Aldh2 $\left.2^{\mathrm{E} 487 \mathrm{~K}+/+}, p<10^{-5}\right)$ comparable with the wild-type C57B1/6 mice (Aldh2 $2^{-/-}, p>0.3 ; A l d h 2^{\mathrm{E} 487 \mathrm{~K}+/+}, p>0.4$; Fig. 1D).

\section{Water versus ethanol intake}

Four weeks after vector administration, mice were supplied water or ethanol in their daily drinking bottles for 12 weeks (10\% ethanol in water for the first 6 weeks and 15\% ethanol in water for the second 6 weeks) ad libitum. Water or ethanol intake was measured every week. In all genotypes, water or ethanol intake increased proportionally to the number of mice in the cage (all $r^{2}>0.96, p<10^{-9}$, Supplementary Fig. S3A). Ethanol intake was found to be signifi-

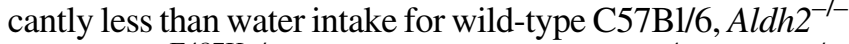
and Aldh $2^{\mathrm{E} 487 \mathrm{~K}+/+}$ mice $\left(\mathrm{C} 57 \mathrm{Bl} / 6, p<10^{-4} ; A l d h 2^{-/-}\right.$, $p<10^{-8}$; Aldh2 $2^{\mathrm{E} 487 \mathrm{~K}+/+}, p<10^{-7}$; Supplementary Fig. S3AC). In contrast, AAVrh.10hALDH2-treated Aldh2 $2^{--}$and Aldh2 $2^{\mathrm{E} 487 \mathrm{~K}+/+}$ mice drank significantly more ethanol than AAVrh.10control-treated mice (Aldh2 $2^{-/}, \quad p<10^{-5}$; Aldh2 $2^{\mathrm{E} 487 \mathrm{~K}+/+}, p<10^{-4}$; Supplementary Fig. S3B, C). 


\section{A hALDH2 mRNA}

$n=5 /$ group

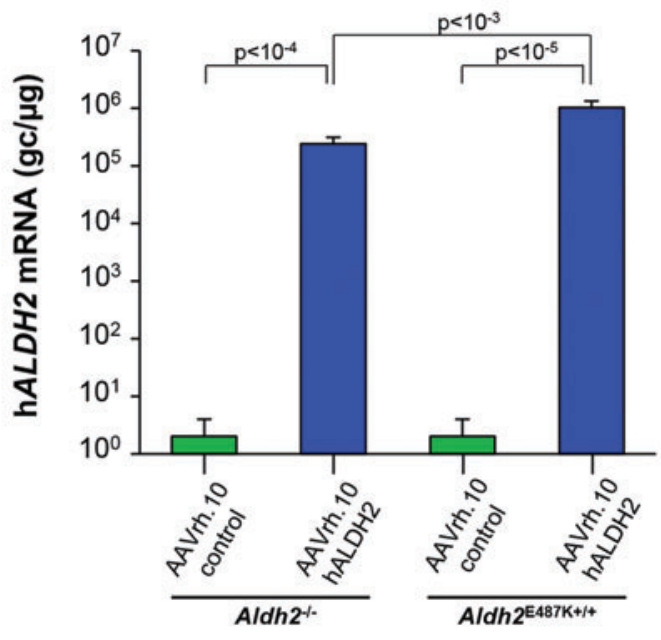

B hALDH2 protein expression

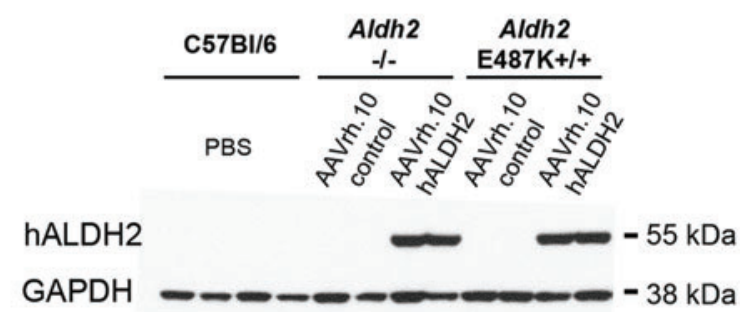

C
AAVrh.10
control

AAVrh.10

hALDH2

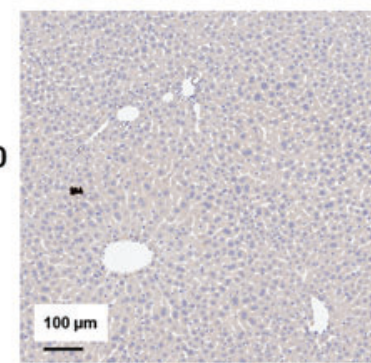

hALDH2 Immunohistochemistry

Aldh2-1-

Aldh2 ${ }^{\mathrm{E} 487 \mathrm{~K}+/+}$
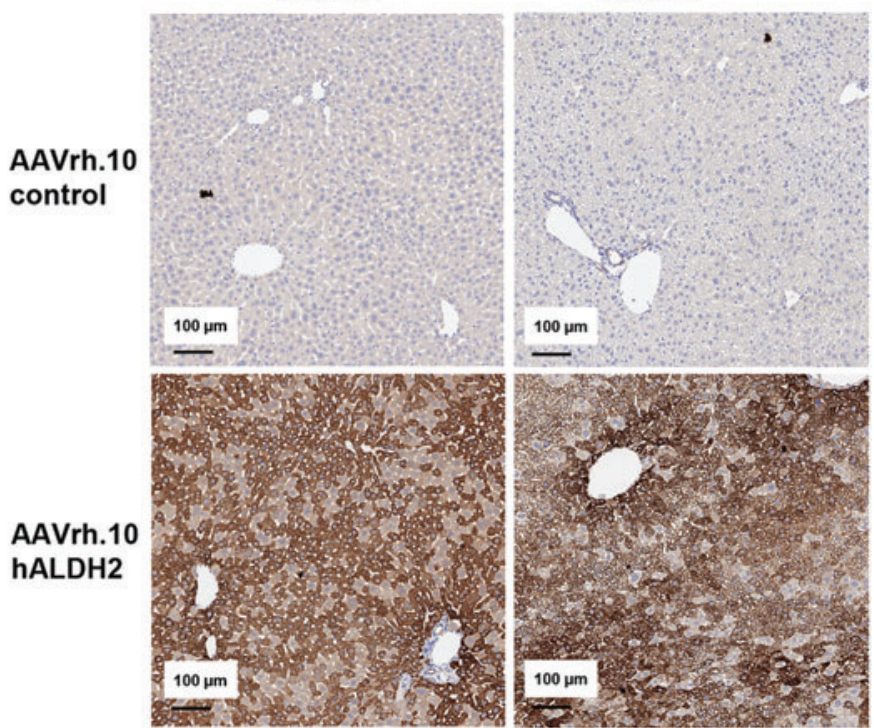

ALDH2 enzymatic activity

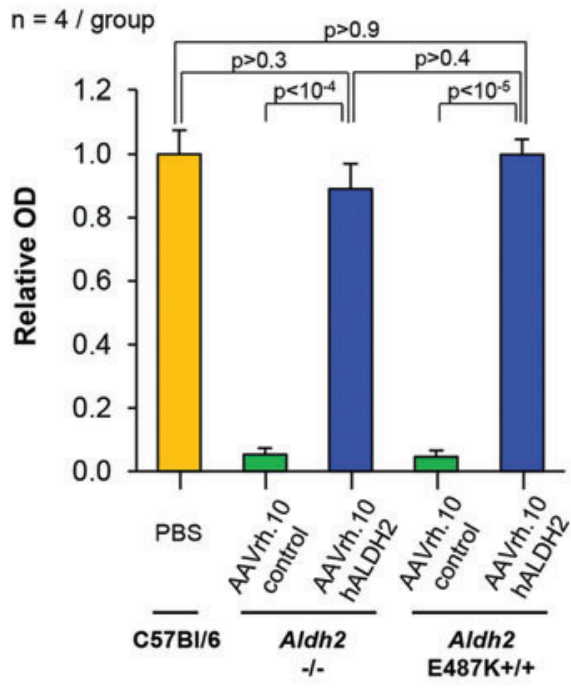

Figure 1. In vivo liver expression of human ALDH2 12 weeks after a single intravenous administration of AAVrh.10hALDH2 or AAVrh.10control (10 ${ }^{11} \mathrm{gc}$ ) to

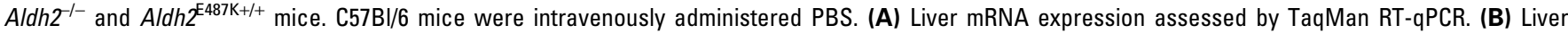
protein expression assessed by Western analysis using an anti-HA tag antibody. GAPDH was used as a loading control. Quantification was assessed on the protein bands from the Western analysis. Two examples of Western analysis from each group are shown; each lane represents a different animal. (C) Liver hALDH2 immunohistochemistry assessed using an anti-HA antibody. (D) Liver ALDH2 enzymatic activity. Data are presented as means \pm SEM. ALDH2, aldehyde dehydrogenase type 2; HA, hemagglutinin; PBS, phosphate-buffered saline; SEM, standard error of the mean. Color images are available online. 


\section{Systemic acetaldehyde and MDA levels after chronic ethanol exposure}

To assess whether augmentation of ALDH2 enzyme levels in the liver by gene therapy could prevent the effects

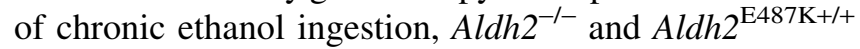
mice were administered AAVrh.10hALDH2 or AAVrh .10control intravenously 4 weeks before the addition of ethanol in the daily water supply. Serum acetaldehyde levels of AAVrh.10control-treated Aldh2 ${ }^{-1-}$ and Aldh $2^{\mathrm{E} 487 \mathrm{~K}+/+}$ mice given ethanol were significantly higher than those of mice given water for 12 weeks $\left(A l d h 2^{-/}\right.$, $p<10^{-2}$; Aldh $2^{\mathrm{E} 487 \mathrm{~K}+/+}, p<0.02$; Fig. 2A). However, serum acetaldehyde levels in AAVrh.10hALDH2 vector- treated Aldh2 $2^{-/-}$and Aldh $2^{\mathrm{E} 487 \mathrm{~K}+/+}$ mice given ethanol for 12 weeks were reduced to levels similar to the $A l d h 2^{-1-}$ or Aldh2 ${ }^{\mathrm{E} 487 \mathrm{~K}+/+}$ mice given water and the wild-type C57B1/6 mice given ethanol (all $p>0.7$, Fig. 2A). In addition to metabolizing acetaldehyde, ALDH 2 also processes reactive aldehydes derived from oxidative stress such as MDA, which is implicated in DNA adduct formation and mutagenesis. ${ }^{35,36}$ The level of MDA in the livers of AAVrh

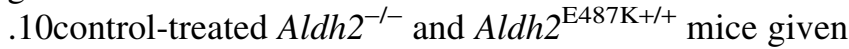
ethanol for 12 weeks was significantly higher than that of mice given water $\left(\right.$ Aldh $2^{-l-}, p<10^{-3} ;$ Aldh $2^{\mathrm{E} 487 \mathrm{~K}+/+}$, $p<10^{-2}$; Fig. 2B). In contrast, the MDA level in AAVrh.10hALDH2-treated Aldh2 ${ }^{-/-}$and Aldh2 ${ }^{\mathrm{E} 487 \mathrm{~K}+/+}$

\section{A Serum acetaldehyde at 12 wk}

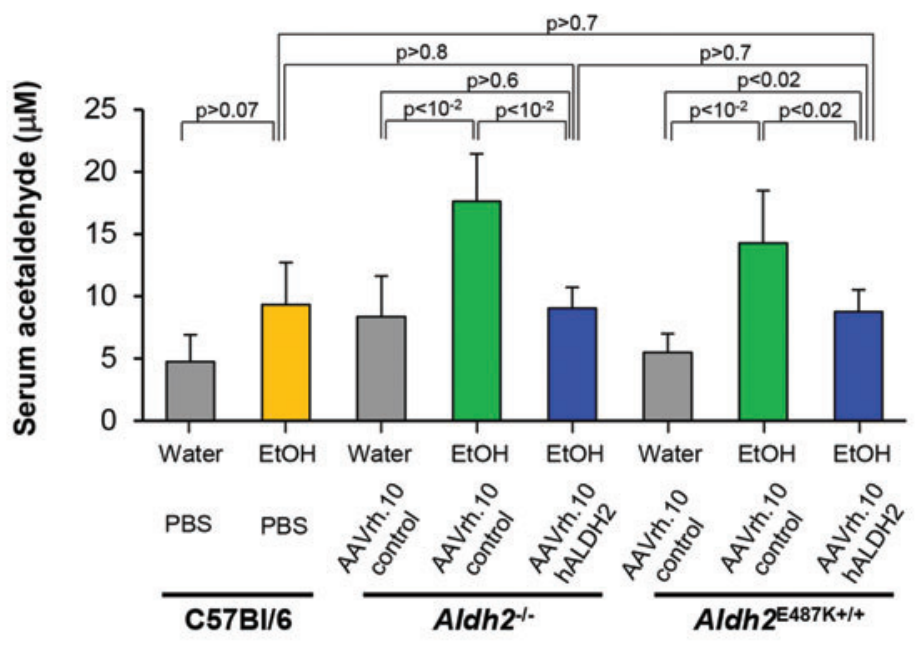

\section{B Liver malondialdehyde (MDA) at 12 wk}

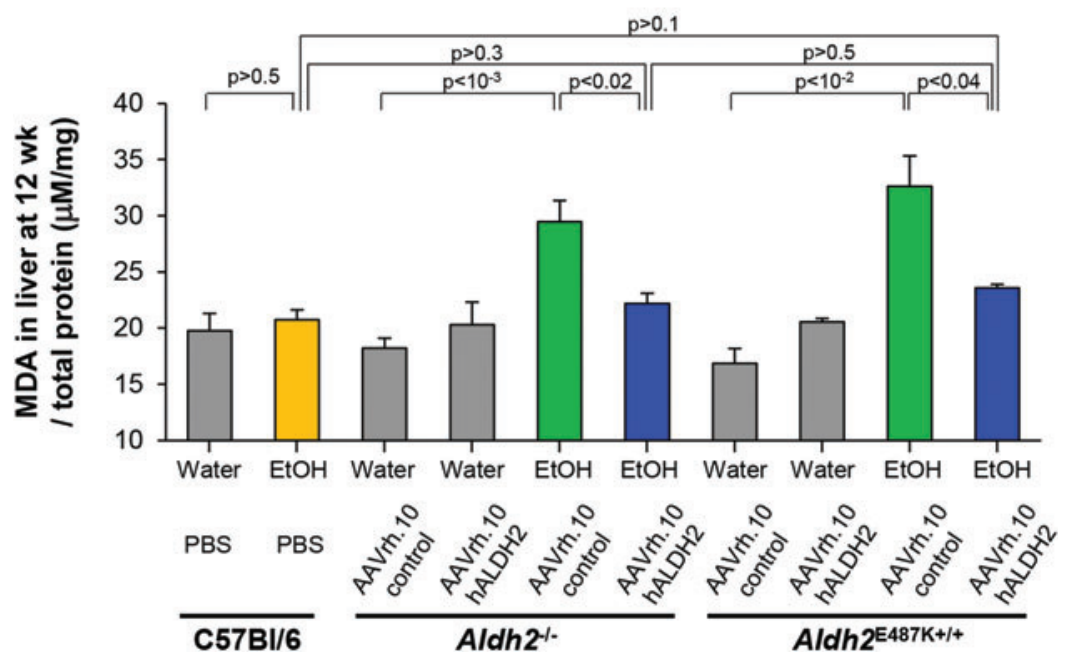

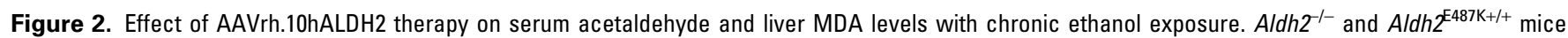
were intravenously administered AAVrh.10hALDH2 $\left(10^{11} \mathrm{gc}\right)$ or AAVrh. 10 control $\left(10^{11} \mathrm{gc}\right)$. C57BI/6 mice were intravenously administered PBS. Four weeks after vector administration, mice were challenged with water or ethanol for 12 weeks. (A) Serum acetaldehyde after 12 weeks chronic ethanol challenge. (B) MDA levels in liver after 12 weeks chronic ethanol exposure, normalized by the amount of total protein. Values are presented as means \pm SEM. MDA, malondialdehyde. Color images are available online. 


\section{A Body weight}
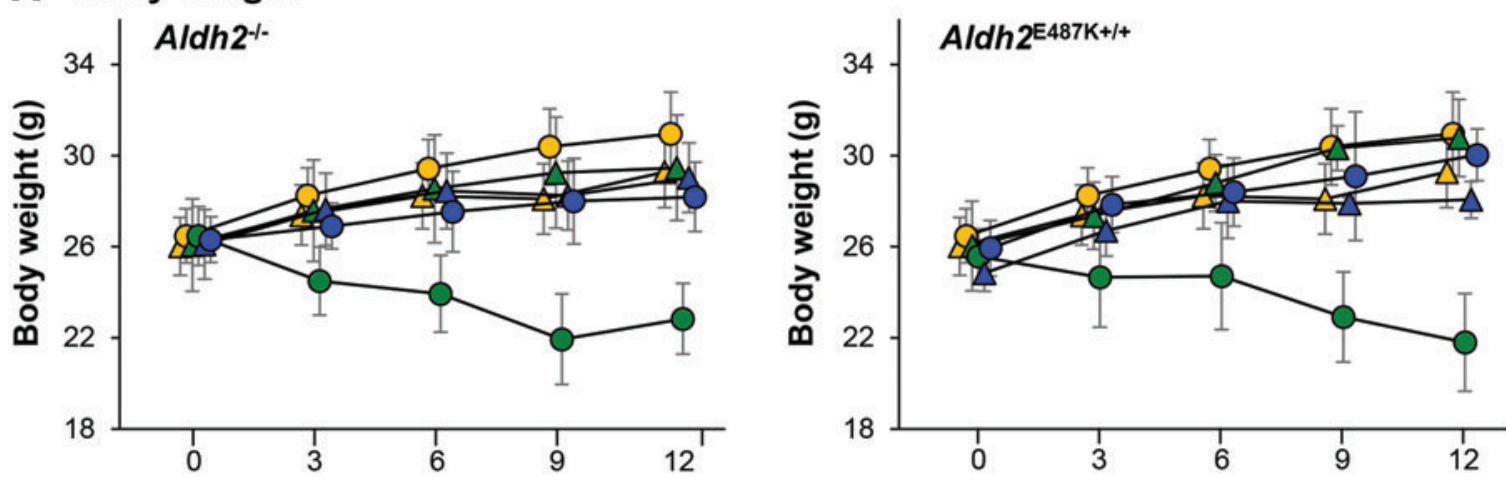

\section{B Hemoglobin}
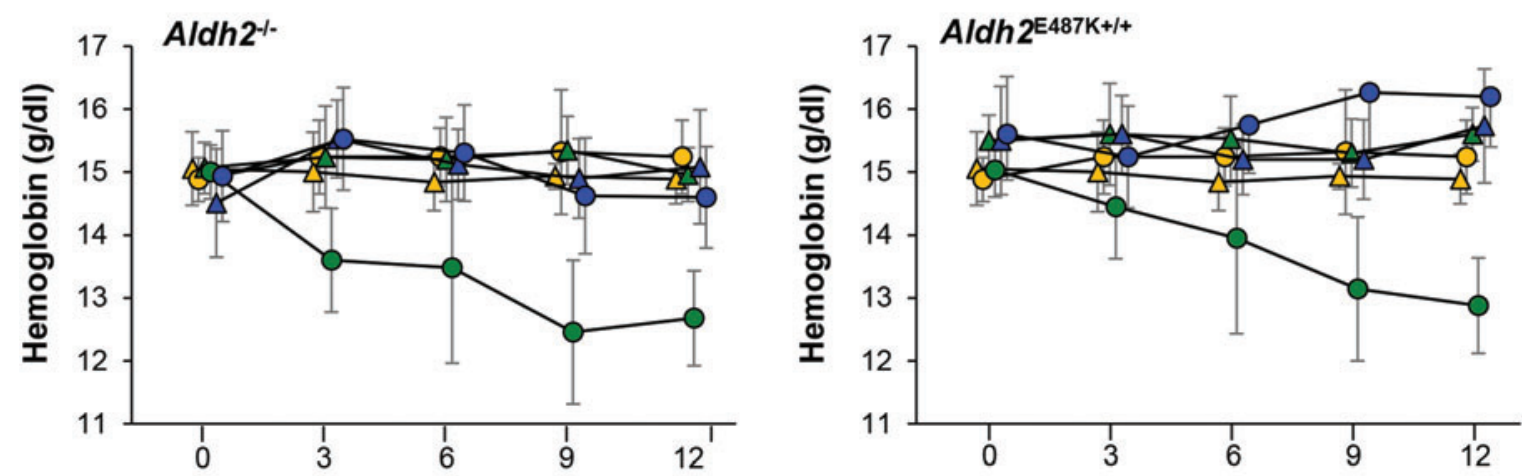

\section{Locomotion (rotarod)}
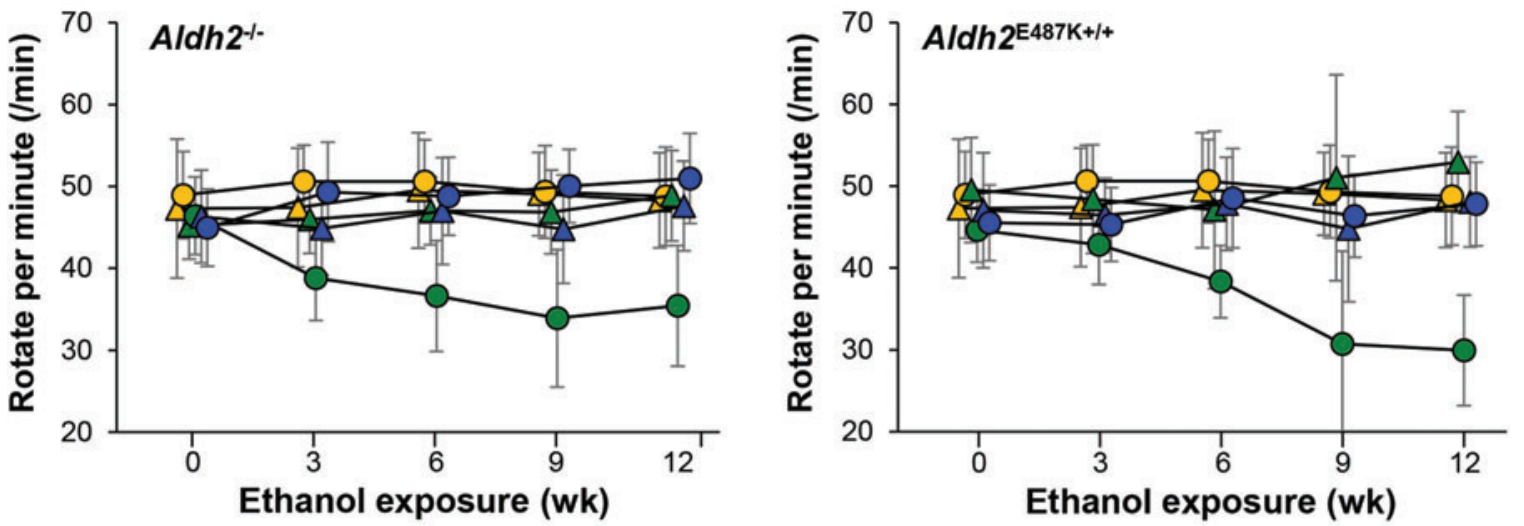

C57BI/6 with PBS and ethanol

\section{C57BI/6 with PBS and ethanol}

$\triangle \mathrm{C} 57 \mathrm{BI} / 6$ with PBS and water

- Aldh $2^{-1-}$ with AAVrh. 10 control and ethanol

$\Delta$ Aldh2 ${ }^{-1-}$ with with AAVrh. 10 control and water

- Aldh2-- with AAVrh.10hALDH2 and ethanol

$\Delta$ Aldh2/- with with AAVrh.10hALDH2 and water
$\triangle$ C57BI/6 with PBS and water
- Aldh $2^{\mathrm{E} 487 \mathrm{~K}+/+}$ with $\mathrm{AAV}$ rh. 10 control and ethanol
$\triangle$ Aldh2 ${ }^{\mathrm{E} 487 \mathrm{~K}+/+}$ with $\mathrm{AAVrh} .10$ control and water
- Aldh2 $2^{\mathrm{E} 487 \mathrm{~K}+/+}$ with $\mathrm{AAVrh} .10 \mathrm{hALDH} 2$ and ethanol

$\triangle$ Aldh2 ${ }^{\mathrm{E} 487 \mathrm{~K}+/+}$ with $\mathrm{AAVrh} .10 \mathrm{hALDH} 2$ and water

Figure 3. Effect of AAVrh.10hALDH2 therapy on body weight, hemoglobin levels, and locomotion (rotarod) during chronic ethanol exposure. Aldh2 $2^{-1-}$ and Aldh $2^{E 487 \mathrm{~K}+/+}$ mice were intravenously administered AAVrh.10hALDH2 $\left(10^{11} \mathrm{gc}\right)$ or AAVrh.10control $\left(10^{11} \mathrm{gc}\right)$. C57BI/6 mice were intravenously administered PBS. Four weeks after vector administration, mice were challenged with water or ethanol for 12 weeks. Tests were performed pre-exposure and 3, 6, 9, and 12 weeks during ethanol exposure. (A) Body weight; (B) hemoglobin; and (C) locomotion (rotarod) assessment of maximum rotations per minute without falling Values are presented as means \pm SEM. Color images are available online. 


\section{A Skin hyperpigmentation}

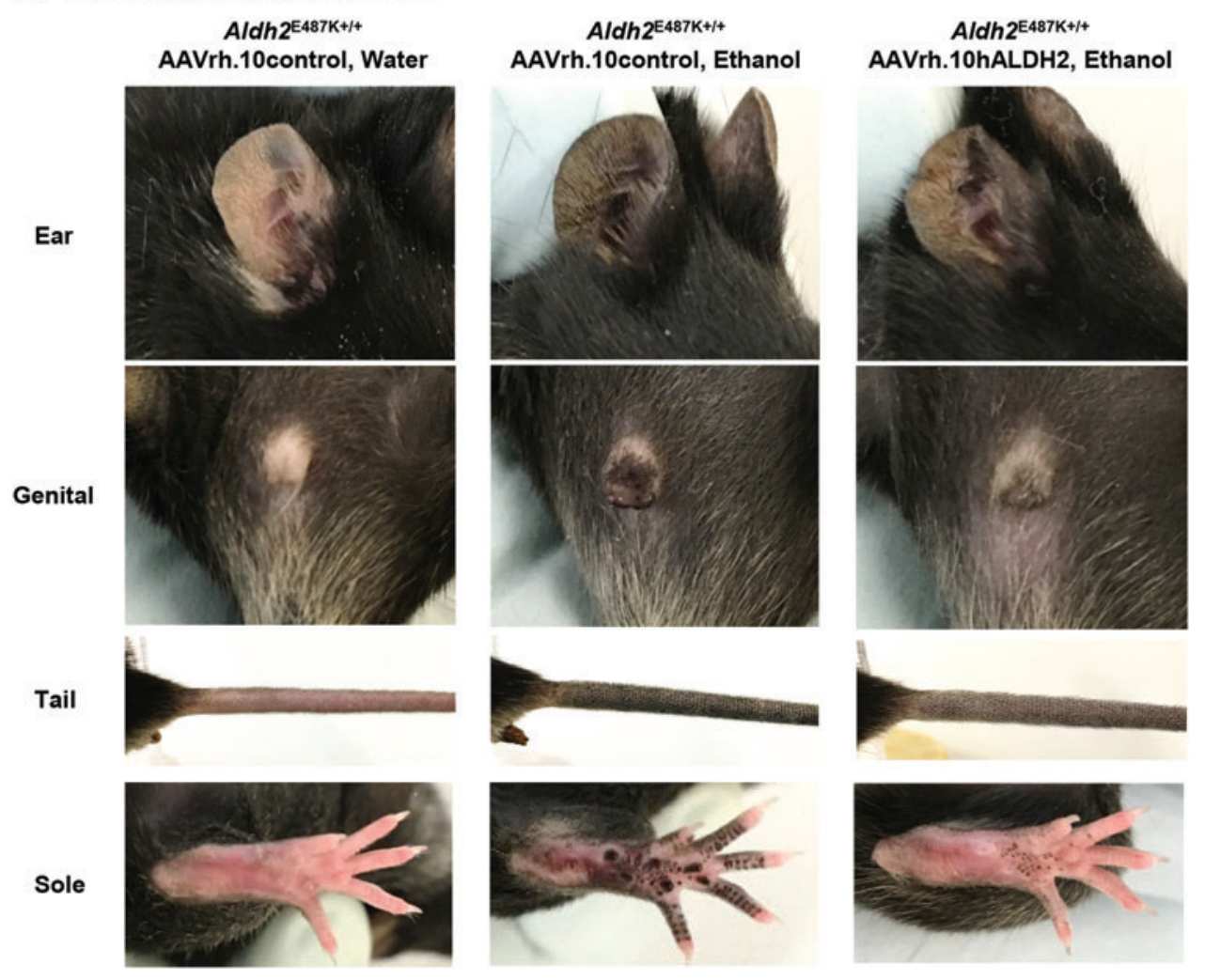

\section{B Level of sole pigmentation}

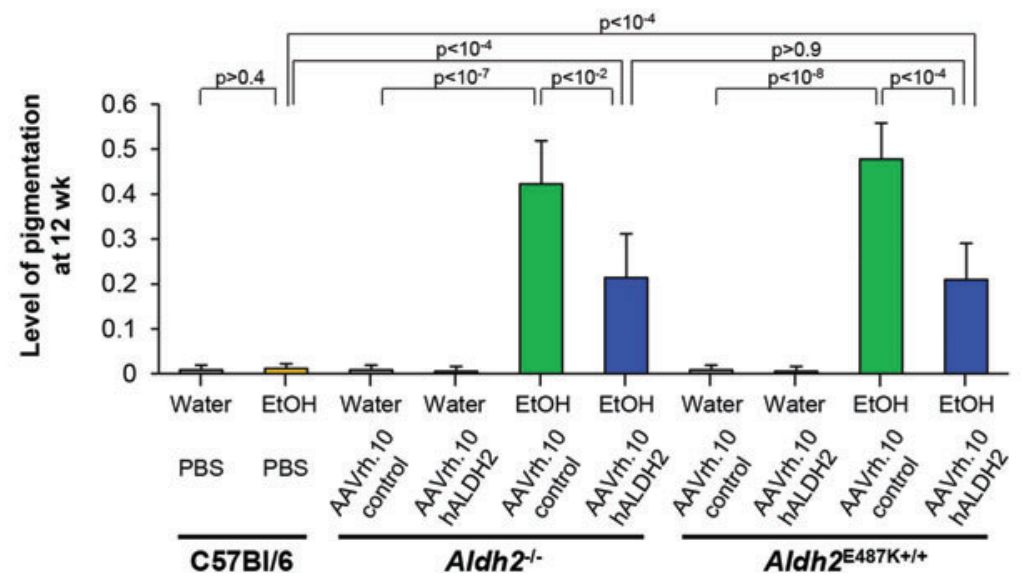

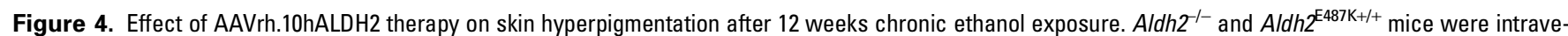
nously administered AAVrh.10hALDH2 $\left(10^{11} \mathrm{gc}\right)$ or AAVrh.10control $\left(10^{11} \mathrm{gc}\right)$. C57B//6 mice were intravenously administered PBS. Four weeks after vector administration, mice were challenged with water or ethanol for 12 weeks. (A) Representative images of pigmentation of ear, genitals, tail, and sole after chronic ethanol challenge. (B) Quantitation of the level of sole pigmentation after chronic ethanol exposure. Values are presented as means \pm SEM. Color images are available online.

mice was not significantly different from that of the ALDH2-deficient mice given water or the wild-type C57Bl/6 mice (all $p>0.1$, Fig. 2B).

\section{Body weight, hemoglobin, locomotion, and dermatological abnormalities}

Prior studies have demonstrated that with chronic ethanol ingestion, Aldh $2^{-/-}$and $A l d h 2^{\mathrm{E} 487 \mathrm{~K}+/+}$ mice have decreased body weight and blood cell counts. ${ }^{9,37}$ To assess whether AAVrh.10hALDH2 therapy could prevent these effects of chronic ethanol consumption, mice were evaluated every 3 weeks for body weight, hemoglobin levels, and rotarod locomotion. Body weight and blood hemoglobin levels of AAVrh.10control-treated Aldh2 ${ }^{-/-}$and Aldh $2^{\mathrm{E} 487 \mathrm{~K}+/+}$ mice decreased significantly for 12 weeks (Fig. 3A and Supplementary Fig. S4A, body weight, 
$p<10^{-3}$; Fig. 3B and Supplementary Fig. S4B, hemoglobin, $p<10^{-5}$ ). In parallel, these mice performed poorly on the rotarod test of locomotion $\left(p<10^{-2}\right.$, Fig. $3 \mathrm{C}$ and Supplementary Fig. S4C). However, the body weight, hemoglobin levels, and rotarod performance for ALDH2deficient mice treated with AAVrh.10hALDH2 were similar to those of the wild-type C57B1/6 mice given ethanol for 12 weeks (Fig. 3 and Supplementary Fig. S4).

$A L D H 2 * 2$ individuals as well as ALDH2-deficient mice develop skin hyperpigmentation with chronic etha- nol consumption. ${ }^{37,38}$ AAVrh.10control-treated Aldh2 ${ }^{-/-}$ and $A l d h 2^{\mathrm{E} 487 \mathrm{~K}+/+}$ mice had increased pigmentation on the skin of the ears, genitals, tail, and soles with chronic ethanol ingestion, compared with littermates given water (Fig. 4A). Quantification of sole pigmentation showed

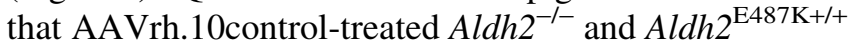
mice with chronic ethanol ingestion had significantly higher levels of sole pigmentation than the ALDH2deficient mice with water or the wild-type C57B1/6 mice (all $p<10^{-7}$, Fig. 4B and Supplementary 5A, B). In

\section{A yH2AX positive cells in esophagus, immunohistochemistry}

C57BI/6 with

PBS and EtOH

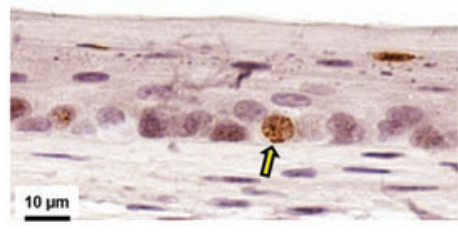

Aldh2-/- with AAVrh.10control and EtOH

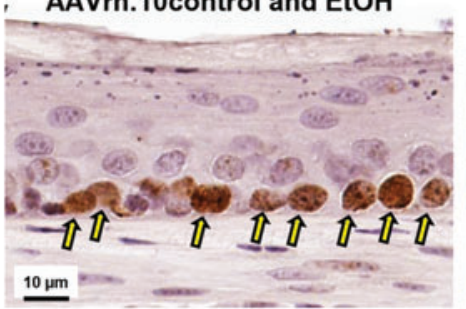

Aldh2 $2^{-1-}$ with

AAVrh.10hALDH2 and water

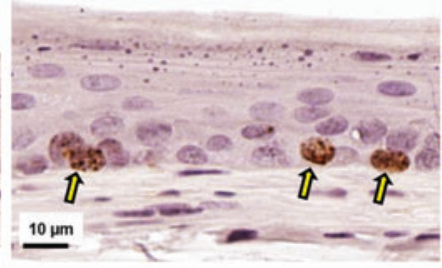

Aldh2\% with

AAVrh.10hALDH2 and EtOH

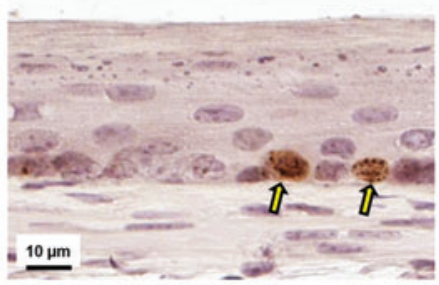

\section{B Quantification of $\mathrm{yH} 2 \mathrm{AX}$ positive cells in esophagus}

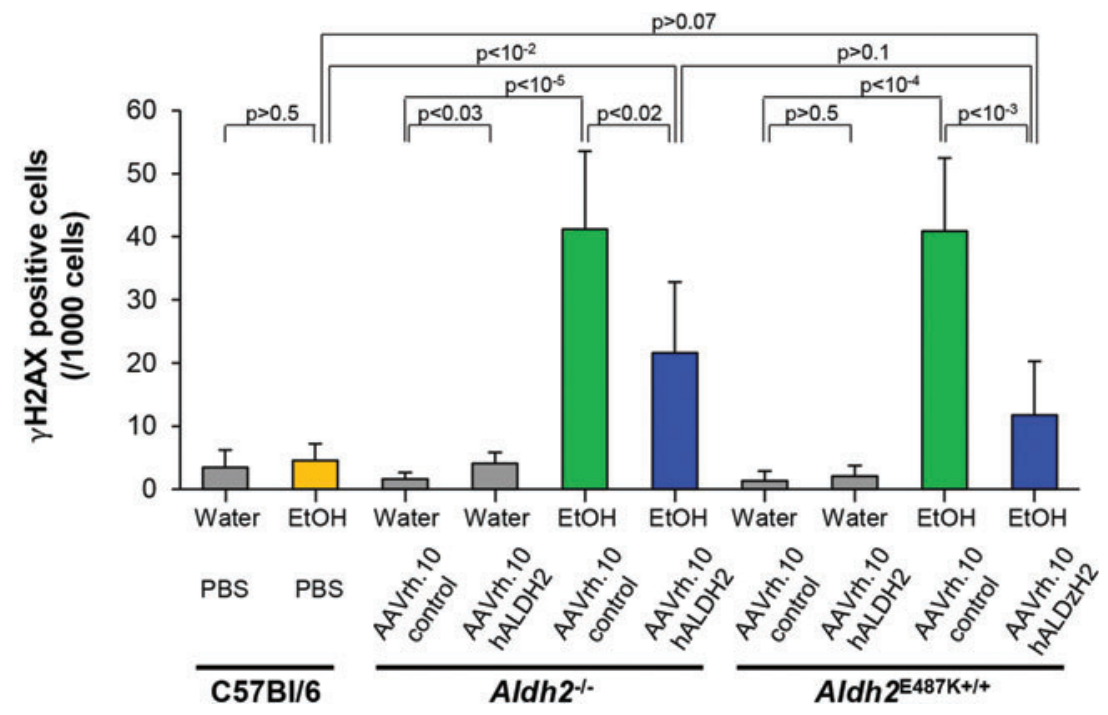

Figure 5. Effect of AAVrh.10hALDH2 therapy on $\gamma \mathrm{H} 2 \mathrm{AX}$-positive cells in the esophageal epithelium after 12 weeks chronic ethanol exposure. Aldh2 $2^{-1-}$ and Aldh2 ${ }^{\mathrm{E} 487 \mathrm{~K}+/+}$ mice were intravenously administered AAVrh.10hALDH2 $\left(10^{11} \mathrm{gc}\right)$ or AAVrh.10control $\left(10^{11} \mathrm{gc}\right)$. C57BI/6 mice were intravenously administered PBS. Four weeks after vector administration, mice were challenged with water or ethanol for 12 weeks. (A) Representative immunohistochemical staining of

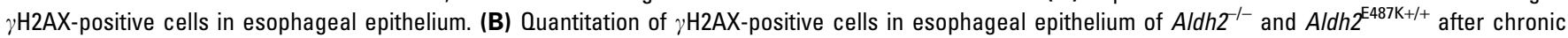
ethanol exposure. Values are presented as means \pm SEM. Color images are available online. 
comparison, sole pigmentation of AAVrh.10hALDH2treated mice with ethanol exposure was significantly less than that of AAVrh.10control-treated mice (Aldh2 ${ }^{-/}$, $p<10^{-2} ;$ Aldh2 ${ }^{\mathrm{E} 487 \mathrm{~K}+/+}, p<10^{-4}$; Fig. 4B).

\section{Esophageal damage after chronic ethanol challenge}

Ethanol and acetaldehyde treatment of ALDH2deficient mouse models leads to accumulation of molecular and genetic changes including DNA damage and adducts that are the precursors of the genetic mutations leading to esophageal cancer development in humans. ${ }^{27,39}$ Acetaldehyde predominantly induces double-strand breaks, and phosphorylated $\mathrm{H} 2 \mathrm{~A}$ histone family member $\mathrm{X}(\gamma \mathrm{H} 2 \mathrm{AX})$ is a well-established marker for detecting these lesions. ${ }^{27,40}$ Immunohistochemistry using a specific $\gamma \mathrm{H} 2 \mathrm{AX}$ antibody was performed on longitudinal esophageal sections of mice chronically treated with ethanol or water, and the number of positive cells in the epithelial

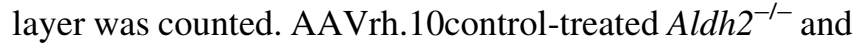
Aldh2 ${ }^{\mathrm{E} 487 \mathrm{~K}+/+}$ mice with ethanol exposure had significantly more $\gamma \mathrm{H} 2 \mathrm{AX}$-positive cells in the esophageal epithelium than mice given water $\left(A l d h 2^{--}, p<10^{-5}\right.$; Aldh $2^{\mathrm{E} 487 \mathrm{~K}+/+}, p<10^{-4}$; Fig. 5A, B) and the wild-type C57B1/6 mice (Aldh2 ${ }^{-/-}, p<10^{-4} ;$ Aldh2 ${ }^{\mathrm{E} 487 \mathrm{~K}+/+}, p<10^{-4}$; Fig. 5A, B). In contrast, the number of $\gamma \mathrm{H} 2 \mathrm{AX}$-positive cells in the esophageal epithelium of AAVrh.10hALDH2treated $A l d h 2^{-/-}$and Aldh2 $2^{\mathrm{E} 487 \mathrm{~K}+/+}$ mice with ethanol exposure was significantly reduced compared with AAVrh.10control-treated mice (Aldh $2^{-/-}, \quad p<0.02$; Aldh $2^{\mathrm{E} 487 \mathrm{~K}+/+}, p<10^{-3}$; Fig. 5B). However, the number of $\gamma \mathrm{H} 2 \mathrm{AX}$-positive cells in AAVrh.10hALDH2-treated mice with ethanol was still higher than that in the $A l d h 2^{-1-}$ and Aldh $2^{\mathrm{E} 487 \mathrm{~K}+/+}$ mice given water or the wild-type C57B1/6 mice (both $p<10^{-2}$, Fig. 5B). The extent of DNA damage was correlated with ALDH2 enzymatic activity (Supplementary Fig. S6).

Acetaldehyde also causes mutations leading to esophageal cancer by forming DNA adducts. $\mathrm{N}^{2}$-et-dG is the primary acetaldehyde-derived DNA adduct found in humans and is considered the most sensitive marker for acetaldehyde exposure-related DNA damage in mice. ${ }^{26}$ DNA was extracted from the whole esophagus of mice chronically exposed to ethanol or water, and $\mathrm{N}^{2}$-et-dG and $\mathrm{dG}$ nucleosides were quantified by LC/MS. AAVrh .10 control-treated Aldh2 $2^{-/-}$and Aldh2 $2^{\mathrm{E} 487 \mathrm{~K}+/+}$ mice had significantly elevated levels of $\mathrm{N}^{2}$-et-dG after 12 weeks of chronic ethanol exposure compared with mice that received water and C57B1/6 wild-type mice (all $p<10^{-3}$, Fig. 6). AAVrh.10hALDH2 treatment significantly reduced the number of $\mathrm{N}^{2}$-et-dG adducts in the esophageal DNA compared with AAVrh.10control-

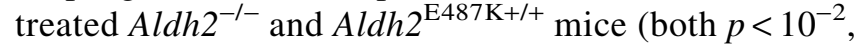
Fig. 6).

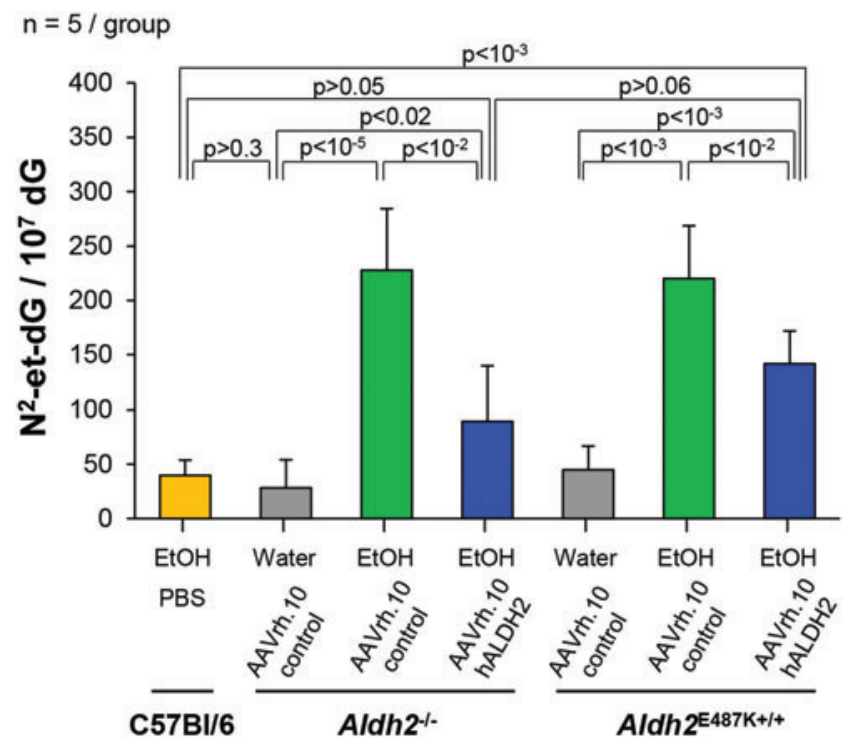

Figure 6. Effect of AAVrh.10hALDH2 therapy on DNA adducts in the

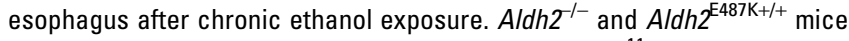
were intravenously administered AAVrh.10hALDH2 $\left(10^{11} \mathrm{gc}\right)$ or AAVrh.10control $\left(10^{11} \mathrm{gc}\right)$. C57BI/6 mice were intravenously administered PBS. Four weeks after vector administration, mice were challenged with water or ethanol for 12 weeks. DNA was extracted from whole esophagus and $\mathrm{N}^{2}$-et$\mathrm{dG}$ adducts were quantified by liquid chromatography tandem mass spectrometry. Values are presented as means \pm SEM. $\mathrm{N}^{2}$-et-dG, $\mathrm{N}^{2}$-ethyl-2'deoxyguanosine. Color images are available online.

\section{Skeletal phenotypes of AAVrh.10hALDH2- treated ALDH2-deficient mice}

Chronic ethanol ingestion by Aldh2 knockout mice results in decreased bone mass compared with wild-type mice, ${ }^{41}$ and transgenic mice overexpressing the $A L D H 2 * 2$ allele have reduced bone mass compared with wild-type controls. ${ }^{20}$ After 12 weeks of ad libitum chronic ethanol consumption, femurs from all mice were analyzed by $\mu \mathrm{CT}$ scans of the trabecular bone and midshaft cortex. ${ }^{42,43}$ C57Bl/6 mice given water or ethanol had similar trabec-

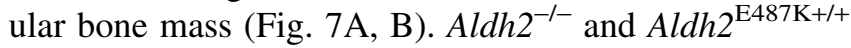
mice administered AAVrh.10control or AAVrh.10hALDH2 and given water had trabecular bone mass similar to C57Bl/6 mice (Fig. 7C, E, G, I). In striking contrast, Aldh $2^{-/-}$and Aldh2 $2^{\mathrm{E} 487 \mathrm{~K}+/+}$ mice administered AAVrh.10control with chronic ethanol ingestion had severe loss of trabecular bone mass compared with mice given water or C57Bl/6 wild-type mice given either water or ethanol

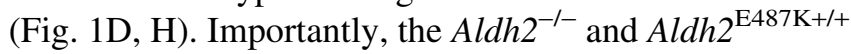
mice treated with AAVrh.10hALDH2 gene therapy with ethanol consumption had significantly increased trabecular bone mass compared with AAVrh.10control-treated mice with no visual difference from wild-type mice (Fig. 7F, J).

Data from several parameters gathered from the $\mu \mathrm{CT}$ were assessed including bone volume density (bone volume/total volume) of trabecular bone, thickness of bone cortex at the midshaft, trabecular number, trabecular 
A C57BI/6, water

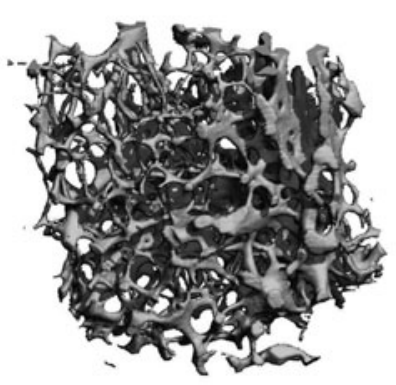

C Aldh2-1-, AAVrh.10control, water

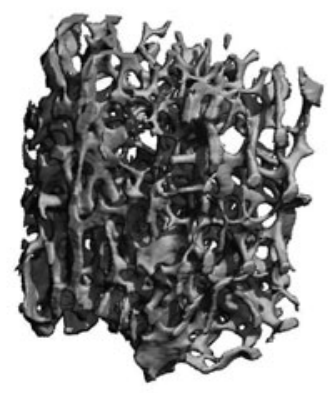

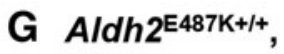
AAVrh.10control, water

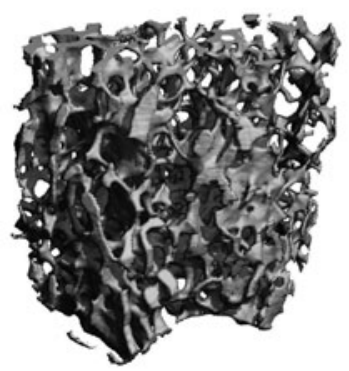

B C57BI/6, ethanol

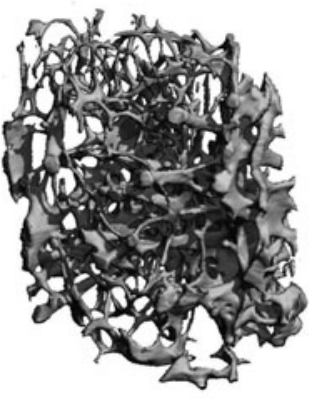

D Aldh2-1,

AAVrh.10control, ethanol

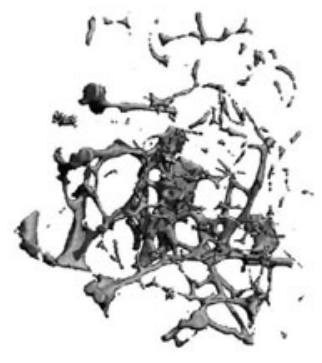
H Aldh2 E487K+/+, $^{2}$ AAVrh.10control, ethanol

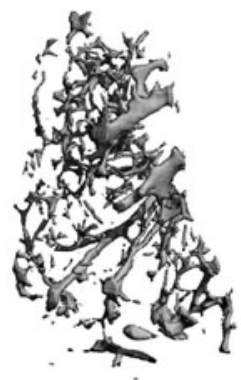

\section{E Aldh2-1, AAVrh.10hALDH2, water}

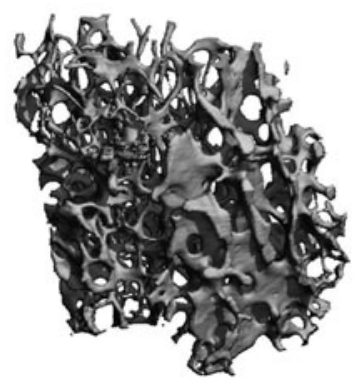
I Aldh2 E487K+/+, $^{2}$ AAVrh.10hALDH2, water

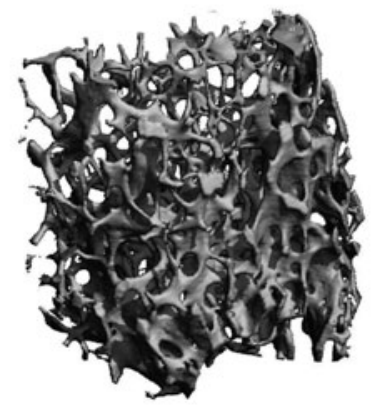

\author{
F Aldh2-1, \\ AAVrh.10hALDH2, \\ ethanol
}

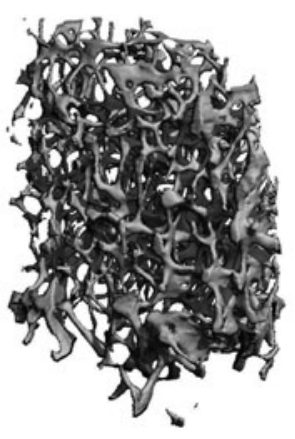

\section{J Aldh2 E487K+/+, $^{2}$ AAVrh.10hALDH2, ethanol}

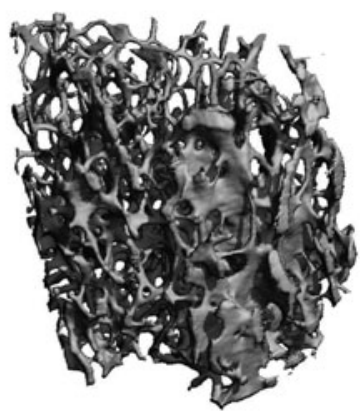

$1 \mathrm{~mm}$

Figure 7. Three-dimensional $\mu \mathrm{CT}$ reconstructions of femur trabecular bone for AAVrh.10hALDH2 therapy after chronic ethanol ingestion. Aldh2 ${ }^{-1-}$ and Aldh $2^{E 487 \mathrm{~K}+/+}$ mice were intravenously administered AAVrh.10hALDH2 $\left(10^{11} \mathrm{gc}\right)$ or AAVrh.10control $\left(10^{11} \mathrm{gc}\right)$. C57BI/6 mice were intravenously administered PBS. Four weeks after vector administration, mice were challenged with water or ethanol for 12 weeks. Fixed femurs were scanned by $\mu$ CT. Shown are representative three-dimensional reconstruction of trabecular bone in metaphysis from one representative animal of each group. (A) C57BI/6 wild-type mice,

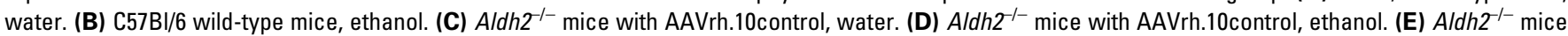

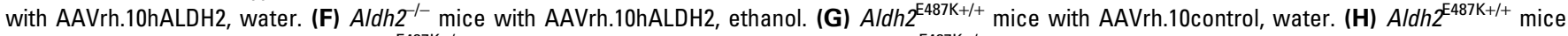
with AAVrh.10control, ethanol. (I) Aldh2 $2^{E 487 \mathrm{~K}+/+}$ mice with AAVrh.10hALDH2, water. (J) Aldh2 $2^{E 487 \mathrm{~K}+/+}$ mice with AAVrh.10hALDH2, ethanol. $\mu \mathrm{CT}$, microcomputed tomography.

thickness, and trabecular space (Fig. 8). The bone volume density of AAVrh.10control-treated Aldh2 ${ }^{-/-}$and Ald$h 2^{\mathrm{E} 487 \mathrm{~K}+/+}$ mice with chronic ethanol ingestion was significantly lower than counterparts given water and C57B1/ 6 wild-type mice with chronic ethanol ingestion (all $p<10^{-2}$, Fig. 8A). These decreases were corrected with
AAVrh.10hALDH2 gene therapy in both $A l d h 2^{-/-}$and Aldh $2^{\mathrm{E} 487 \mathrm{~K}+/+}$ mice (both $p<10^{-2}$, Fig. 8A). Importantly, the bone volume density of AAVrh.10hALDH2-treated Aldh2 $2^{-/-}$and Aldh2 $2^{\mathrm{E} 487 \mathrm{~K}+/+}$ mice with chronic ethanol ingestion was equivalent to that of $\mathrm{C} 57 \mathrm{Bl} / 6$ wild-type mice with ethanol (both $p>0.4$, Fig. 8A). The cortical 


\section{A Bone volume density}

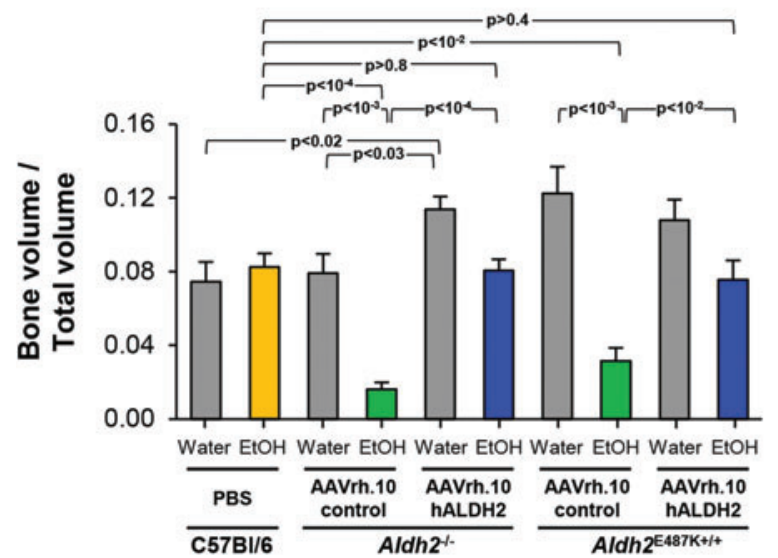

\section{Trabecular number}

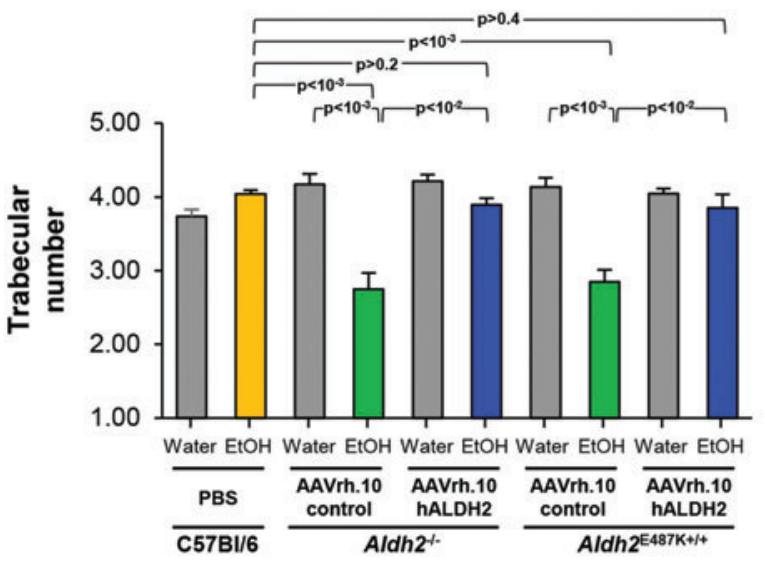

\section{E Trabecular space}

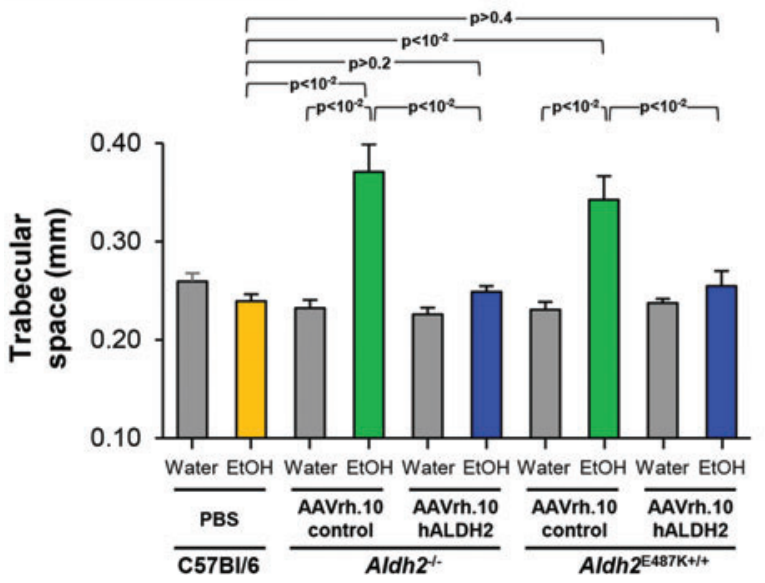

\section{B Thickness of bone cortex}

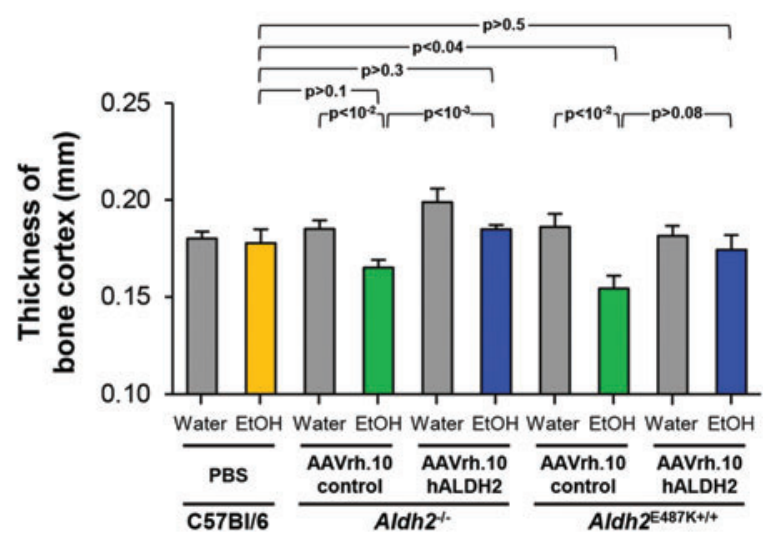

D Trabecular thickness

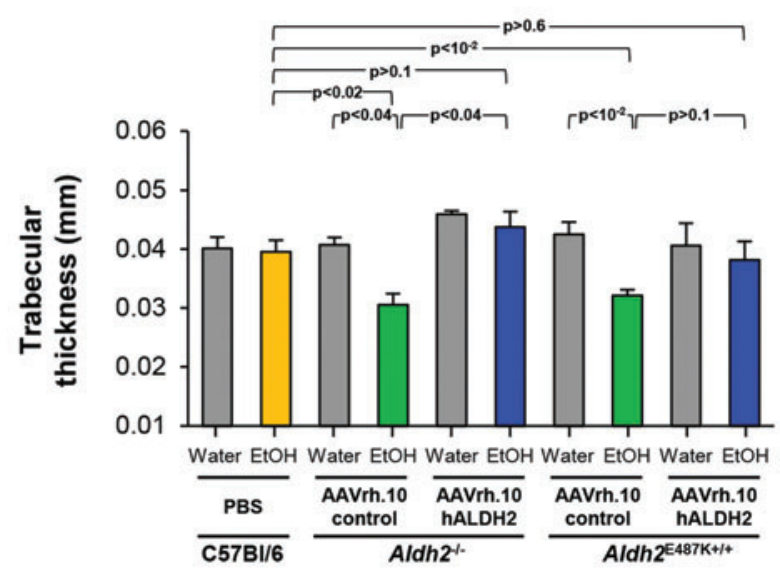

Figure 8. Quantitative $\mu \mathrm{CT}$ assessment of AAVrh.10hALDH2 therapy on bone structure of femurs of ALDH2-deficient mice after chronic ethanol ingestion.

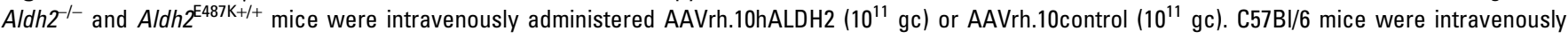
administered PBS. Four weeks after vector administration, mice were challenged with water or ethanol for 12 weeks. Fixed femurs were scanned by $\mu$ CT at the trabecular bone and midshaft cortex. (A) Bone volume density (bone volume/total volume). (B) Thickness of bone cortex. (C) Trabecular number. (D) Trabecular thickness. (E) Trabecular space. Values are presented as means \pm SEM; $n=5 /$ group. Color images are available online. 
A C57BI/6, water

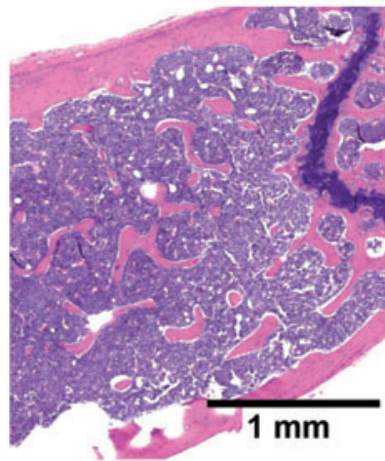

C Aldh2 - , AAVrh.10control, water

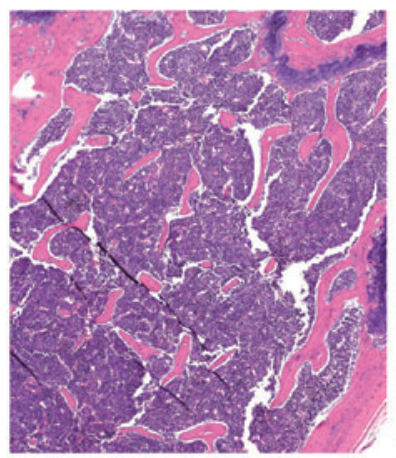

\section{B C57BI/6, ethanol}

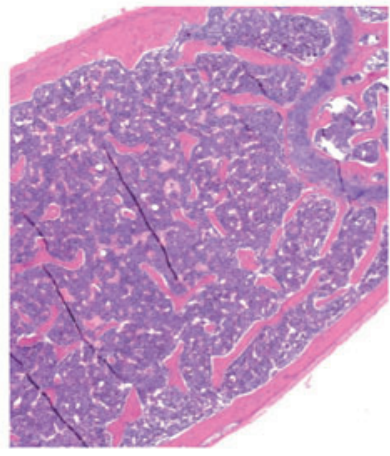
D Aldh2-- AAVrh.10control, ethanol

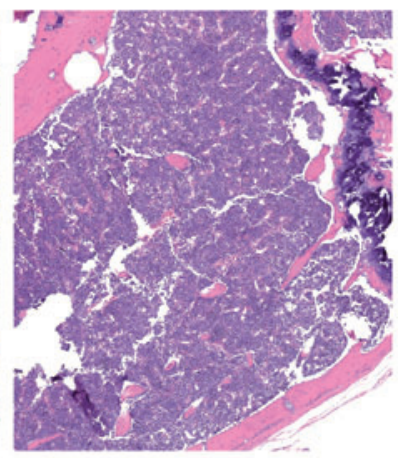

\section{E Aldh2 ${ }^{-1}$, AAVrh.10hALDH2, water \\ F}

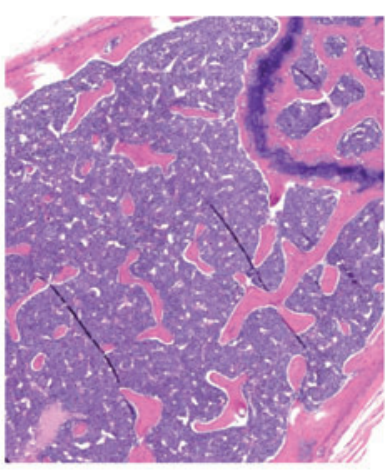

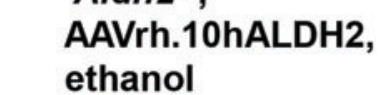

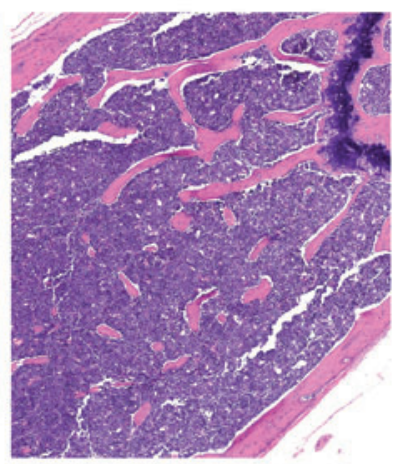

\section{Aldh2 ${ }^{\mathrm{E} 487 \mathrm{~K}+/+}$, J water}

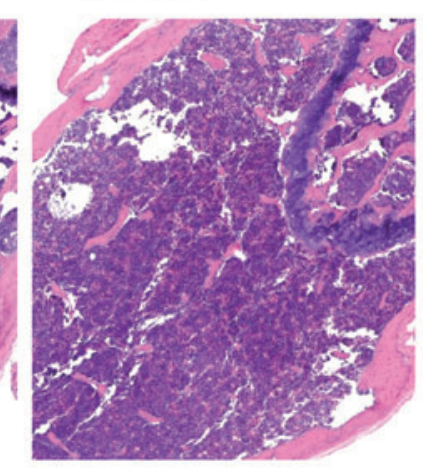

\section{Aldh2E487K+/+, AAVrh.10hALDH2, ethanol}
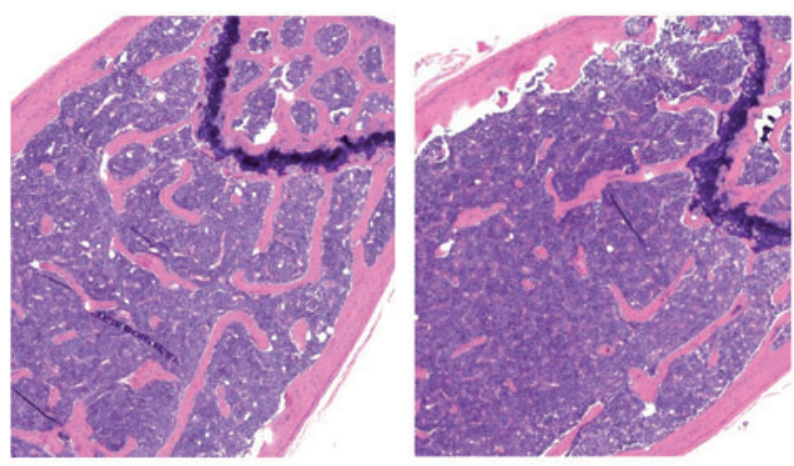

Figure 9. Histological assessment of AAVrh.10hALDH2 therapy on femurs of ALDH2-deficient mice after chronic ethanol ingestion. Aldh2 ${ }^{-/-}$and $A l d h 2^{E 487 K+/+}$ mice were intravenously administered AAVrh.10hALDH2 $\left(10^{11} \mathrm{gc}\right)$ or AAVrh.10control $\left(10^{11} \mathrm{gc}\right)$. C57BI/6 mice were intravenously administered PBS. Four weeks after vector administration, mice were challenged with water or ethanol for 12 weeks. Fixed decalcified femurs were embedded in paraffin and longitudinal sections were stained with hematoxylin and eosin. Examples from animals in each group are shown. (A) C57BI/6 wild-type mice, water. (B) C57BI/6 wild-type

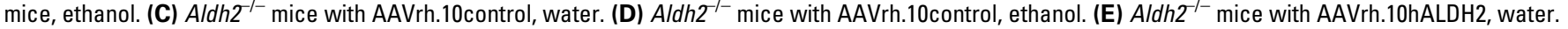

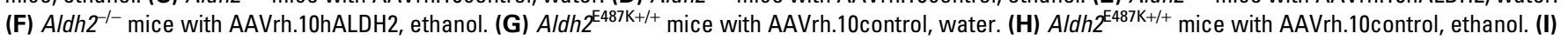
Aldh $2^{\mathrm{E} 487 \mathrm{~K}+/+}$ mice with AAVrh.10hALDH2, water. ( J) Aldh2 ${ }^{\mathrm{E} 487 \mathrm{~K}+/+}$ mice with AAVrh.10hALDH2, ethanol. Scale bar $=1 \mathrm{~mm}$. Color images are available online. 
thickness of AAVrh.10control-treated Aldh2 $2^{-/}$and Ald$h 2^{\mathrm{E} 487 \mathrm{~K}+/+}$ mice with chronic ethanol ingestion was significantly lower than the mice given water (both $p<10^{-2}$, Fig. $8 \mathrm{~B}$ ) and $\mathrm{C} 57 \mathrm{Bl} / 6$ wild-type mice with chronic ethanol ingestion $\left(A l d h 2^{\mathrm{E} 487 \mathrm{~K}+/+}, p<0.04 ; A l d h 2^{-/-}, p>0.1\right.$; Fig. 8B). The cortical thickness was increased by AAVrh.10hALDH2 treatment equivalent to that of C57B1/ 6 mice in both $A l d h 2^{-/-}$and $A l d h 2^{\mathrm{E} 487 \mathrm{~K}+/+}$ mice $\left(A l d h 2^{-/-}\right.$, $p>0.3 ; A l d h 2^{\mathrm{E} 487 \mathrm{~K}+/+}, p>0.5$; Fig. 8B). The trabecular number and trabecular thickness for AAVrh.10controltreated Aldh2 $2^{-/-}$and Aldh2 $2^{\mathrm{E} 487 \mathrm{~K}+/+}$ mice with chronic ethanol ingestion were both lower (all $p<0.04$, Fig. 8C, D), whereas the trabecular space parameter was significantly greater than that of either ALDH2-deficient mice with water or $\mathrm{C} 57 \mathrm{Bl} / 6$ mice with chronic ethanol ingestion $\left(p<10^{-2}\right.$; Fig. 8E). All of these parameters were significantly corrected by AAVrh.10hALDH2 therapy in both Aldh2 $2^{-/-}$and Aldh2 $2^{\mathrm{E} 487 \mathrm{~K}+/+}$ mice to measurements equivalent to $\mathrm{C} 57 \mathrm{Bl} / 6$ mice with chronic ethanol ingestion (all $p>0.1$, Fig. 8C-E).

Longitudinal sections of the femurs were stained for histological analysis with hematoxylin and eosin (Fig. 9). The histological findings support the results of the $\mu \mathrm{CT}$ scans. Femur histology of C57Bl/6 wild-type mice given either water or ethanol had no visible differences (Fig. 9B). Histological assessment of $\mathrm{Aldh}^{-/-}$and Aldh2 $2^{\mathrm{E} 487 \mathrm{~K}+/+}$ mice administered AAVrh.10control and given water showed no notable difference from that of wild-type mice (Fig. 9C, E, G, I). However, the presence of trabecular bone in the metaphysis of AAVrh .10control-treated Aldh2 $2^{-/-}$and Aldh2 $2^{\mathrm{E} 487 \mathrm{~K}+/+}$ mice after chronic ethanol ingestion was significantly reduced (both $p<10^{-2}$, Fig. 9D, H and Supplementary Fig. S7). Interestingly, AAVrh.10hALDH2 vector-treated Aldh2 ${ }^{-1-}$ and $A l d h 2^{\mathrm{E} 487 \mathrm{~K}+/+}$ mice with ethanol had significantly more trabecular bone than AAVrh.10control vectortreated Aldh2 $2^{-/-}$and $A l d h 2^{\mathrm{E} 487 \mathrm{~K}+/+}$ mice given ethanol (both $p<10^{-3}$, Fig. 9F, J and Supplementary Fig. S7). Indeed, the trabecular bone levels with AAVrh.10hALDH2 treatment were similar to the levels of trabecular bone in mice given water $\left(A l d h 2^{-/-}, p<0.02 ; A l d h 2^{\mathrm{E} 487 \mathrm{~K}+/+}\right.$, $p>0.8$; Supplementary Fig. S7) or wild-type mice given ethanol (Aldh2 $2^{-/-}, p>0.07$; Aldh2 $2^{\mathrm{E} 487 \mathrm{~K}+/+}, p>0.3$; Supplementary Fig. S7).

\section{DISCUSSION}

ALDH2 deficiency is one of the most common hereditary disorders affecting 560 million people, $\sim 8 \%$ of the world population, including 35-45\% of East Asian descendants. ${ }^{1-3}$ ALDH2 is a key enzyme in the ethanol metabolism pathway and works primarily in the liver converting acetaldehyde to acetate. ${ }^{5,7}$ The most common genetic variant causing this deficiency is a glutamic acidto-lysine substitution at position 487 (E487K) designated the $A L D H 2 * 2$ allele. ${ }^{3,14}$ Heterozygote and homozygote individuals for the $A L D H 2 * 2$ allele have reduced enzymatic activity and ability to process acetaldehyde. ${ }^{12,13}$ The ALDH2 enzyme is a tetramer and the mutant protein functions as a dominant negative ${ }^{10,11}$; heterozygotes have $<50 \%$ ALDH2 enzymatic activity and homozygotes $<4 \%{ }^{12,13}$ The major consequence of the mutation comes from accumulation of acetaldehyde primarily after ethanol consumption. The acute response to ethanol of individuals with ALDH2 deficiency is the famous "Asian flush syndrome," appearing as alcohol-induced facial flushing, tachycardia, nausea, and headaches. ${ }^{3,13}$ ALDH2 deficiency is also linked with a number of serious chronic medical disorders, including neurological, endocrine, cardiovascular and dermatological disorders, and aberrant drug metabolism. ${ }^{2,3}$ Importantly, the $A L D H 2 * 2$ allele is associated with a marked 7-12-fold increase in the risk of upper aerodigestive tract cancer of the oral cavity, pharynx, larynx, and esophagus with chronic ethanol ingestion. ${ }^{3,17}$ Individuals carrying the $A L D H 2 * 2$ allele who also smoke cigarettes and consume alcohol have a very high cancer risk (odds ratio 50:1) with a 25-year earlier onset of esophageal carcinoma. ${ }^{1,44,45}$ In addition to the high risk for aerodigestive cancer, chronic ethanol consumption with ALDH2 deficiency is associated with a high risk for osteoporosis. ${ }^{18-24}$ The data demonstrate that pretreatment with AAVrh.10hALDH2, an AAV serotype rh.10 nonhuman primate vector coding for human $A L D H 2$, prevents many of these chronic disorders in two mouse models of ALDH2 deficiency with chronic ethanol consumption.

\section{Body weight, hemoglobin, locomotion, and dermatological abnormalities}

Aldh $2^{-/-}$and Aldh2 $2^{\mathrm{E} 487 \mathrm{~K}+/+}$ mice chronically consuming ethanol had increased serum acetaldehyde levels, higher MDA levels, lower body weight, lower hemoglobin counts, worse performance on a locomotion test, and increased skin hyperpigmentation than wild-type mice or ALDH2-deficient mice given water. All of these abnormal parameters were prevented by pretreatment with AAVrh .10hALDH2 therapy.

Loss of body weight in ALDH2-deficient mice with ethanol consumption has been observed in several previous studies. ${ }^{9,33,46}$ Even without alcohol consumption, the body mass index is lower in individuals with the $A L D H 2 * 2$ allele. ${ }^{47,48}$ Long-term exposure to acetaldehyde impeded growth of Wistar rats in a dose-dependent manner, ${ }^{49}$ suggesting the increased systemic acetaldehyde after ethanol consumption in ALDH2-deficient individuals may contribute to the decreases in body weight.

Hematological abnormalities such as anemia and leukocytopenia are a frequent complication of alcoholism even in normal individuals, ${ }^{50}$ and individuals heterozygous for the $A L D H 2 * 2$ allele who are alcoholics have 
increased susceptibility to these conditions. ${ }^{51}$ In a study of Japanese men, heterozygous $A L D H 2 * 2$ individuals who were moderate to heavy drinkers had lower red cell counts and hemoglobin levels than never or rare drinkers. ${ }^{52}$ In addition, acetaldehyde causes DNA damage in hematopoietic stem cells, impairs blood production, and promotes bone marrow failure. ${ }^{53,54}$ The $A L D H 2 * 2$ allele is associated with increased risk of aplastic anemia and accelerated progression of disease in patients with Fanconi anemia. ${ }^{5,56}$

The $A L D H 2 * 2$ allele is associated with neurodegenerative disorders including Alzheimer's disease and Parkinson's disease. ${ }^{2,57-60}$ Aged Aldh2 ${ }^{-1-} \times$ Aldhlal $^{-1-}$ mice exhibit deficits in motor performance. ${ }^{61}$ ALDH2 also detoxifies two endogenous aldehydes, 4-hydroxynonenal (4-HNE), and 3,4-dihydroxyphenylacetaldehyde (DOPAL), which have been implicated in neurotoxicity and the development of Parkinson's disease. ${ }^{2,61}$ Chinese individuals homozygous for the $A L D H 2 * 2$ allele have a 4.87 -fold increase in the risk for Parkinson's disease. ${ }^{59}$

Chronic alcohol use can precipitate a number of skin disorders including hyperpigmentation. ${ }^{62}$ The hyperpigmentation of exposed skin has been observed in ALDH2deficient mice at levels similar to those of the $A l d h 2^{-/-}$and Aldh $2^{\mathrm{E} 487 \mathrm{~K}+/+}$ mice with chronic ethanol consumption in this study. ${ }^{9,38}$ The mechanism of melanin deposition is not well understood but is dependent on the dose of alcohol. ${ }^{38}$ In humans, esophageal melanosis occurs at higher incidence in individuals with the $A L D H 2 * 2$ allele. Alcoholic Japanese men have a 2.66-fold increased risk for these abnormalities, ${ }^{63}$ suggesting a link to high acetaldehyde exposure as a consequence of the inactive ALDH2 enzyme.

\section{Acetaldehyde and cancer}

Prior studies have shown that esophageal cancer per se cannot be induced with long-term ethanol ingestion in mouse models of ALDH2 deficiency. ${ }^{64,65}$ However, mouse models of ALDH2 deficiency do accumulate more DNA damage and adducts in their esophagus with chronic ethanol ingestion. ${ }^{27,66}$ The carcinogenicity of acetaldehyde has been shown experimentally using long-term acetaldehyde exposure in the water supply of SpragueDawley rats. Increased development of malignant tumors was found in various organs dependent on the acetaldehyde levels. ${ }^{67}$ Acetaldehyde is categorized as a group I human carcinogen by the International Agency for Research on Cancer. ${ }^{68,69}$ Acetaldehyde can form DNA-DNA and DNA-protein cross-links, induce DNA adduct formation, and interfere with DNA replication and the DNA repair machinery., ${ }^{2,70-72}$ Several reports have suggested that the accumulation of acetaldehyde-induced DNA adducts in cells leads to the development of cancer. ${ }^{26,73,74}$ The most abundant of the adducts is $\mathrm{N}^{2}$-et-dG; accumulation of this adduct in the esophagus has been observed in ALDH2-deficient human alcoholics and mice exposed to ethanol and is often used as a biomarker for acetaldehyderelated DNA damage as a precursor of esophageal cancer. ${ }^{27,75}$ Other acetaldehyde-induced adducts, $\alpha$-methyl$\gamma$-OH-propano-deoxyguanosine and $\mathrm{N}^{2}$-(2,6-dimethyl-1, 3-dioxan-4-yl)-deoxyguanosine, are detected in the blood of ALDH2-deficient alcoholics. ${ }^{75}$ Mammalian cells and rodents treated with ethanol or acetaldehyde develop DNA interstrand crosslinks and double-stranded breaks leading to chromosome rearrangements and genomic instability. ${ }^{54,66,70}$

\section{Osteoporosis}

Osteoporosis caused by chronic alcohol consumption is detrimental to quality of life and a significant financial burden on both individuals and society. ${ }^{76,77}$ Worldwide, 67 million individuals $>50$ years old with ALDH2 deficiency are at increased risk for osteoporosis with chronic alcohol intake. ${ }^{2,3,78-80}$ Alcoholism is a risk factor for osteoporosis even in individuals without ALDH2 deficiency. ${ }^{18,21,22}$ Acetaldehyde, the intermediate product of alcohol metabolism, interferes with bone metabolism. ${ }^{19,20,81,82}$ The increased accumulation of serum acetaldehyde resulting from ALDH2 deficiency further increases the risk of developing osteoporosis. ${ }^{2,3,19,20}$

\section{Gene therapy}

We hypothesized that genetic modification of the ALDH2-deficient liver to express the normal human ALDH 2 coding sequence would restore ALDH2 enzymatic function, reduce persistent elevated levels of circulating acetaldehyde, and prevent the ALDH2-deficient phenotypes associated with chronic ethanol consumption. The data demonstrated that administration of AAVrh.10hALDH2 reconstituted ALDH2 protein expression and enzymatic activity in two murine models of ALDH2 deficiency at 16 weeks after administration. In Aldh2 $2^{-/}$and Aldh $2^{\mathrm{E} 487 \mathrm{~K}+/+}$ mice, AAVrh.10hALDH2 treatment corrected chronic ethanol-induced elevated serum acetaldehyde levels and liver MDA levels as well as a variety of abnormal phenotypes including body weight loss, lower hemoglobin levels, poor locomotion, skin pigmentation, esophageal DNA damage and adduct accumulation, and osteopenia.

The results for AAVrh.10hALDH2 gene therapy prevention of chronic ethanol-induced esophageal DNA damage and adducts in the ALDH2-deficient mice are consistent with reports suggesting that Alda-1, a small molecule activator of ALDH2, can reduce the accumulation of DNA damage and adducts in the esophagus of mice with ALDH2 deficiency. ${ }^{64}$ Although AAVrh.10hALDH2 treatment significantly reduced both the number of $\gamma \mathrm{H} 2 \mathrm{AX}$-positive cells and the level of $\mathrm{N}^{2}$-et-dG adducts in the esophagus, these markers of DNA damage remained higher than in ethanol-exposed wild-type mice or ALDH2deficient mice given only water. This may be due to ac- 
etaldehyde produced locally in the esophagus contributing to the induction of DNA damage and ultimately esophageal cancer. ${ }^{64,66,83}$ The data show that AAVrh.10hALDH2 treatment prevents the increased level of circulating acetaldehyde in the blood in ALDH2-deficient mice given alcohol. However, mucosal cells, salivary glands, or microbes in the oral cavity also are able to process ethanol to acetaldehyde after alcohol exposure, which may contribute to acetaldehyde-induced damage in the esophagus. ${ }^{84-86}$ Because AAVrh.10hALDH2 mainly targets the liver and esophageal epithelial cells have a high turnover rate, longterm AAV gene therapy for the esophagus is difficult. However, a liver-directed gene therapy approach may be unable to completely reduce the elevated local levels of acetaldehyde in the oral cavity and esophagus. Even so, our data indicate that reducing the burden of systemic acetaldehyde by restoring ALDH2 expression in the liver substantially lowers the accumulation of DNA damage and DNA adducts that precede esophageal carcinogenesis in ALDH2-deficient mice that chronically consumed ethanol.

$\mu \mathrm{CT}$ quantification and histological assessment of femurs from the ALDH2-deficient mouse models demonstrated that chronic ethanol ingestion for 12 weeks induced osteopenia. Consistent with previous reports, the bone density loss was especially striking in trabecular bone and was also significant in the midshaft cortex..$^{20,41} \mathrm{AAVrh}$ .10hALDH2 therapy prevented the development of osteopenia in ALDH2-deficient mice with chronic ethanol ingestion and maintained bone density similar to C57B1/6 mice with chronic ethanol exposure or ALDH2-deficient mice with water. This is consistent with a previous study showing that the ALDH2 activator Alda- 1 could reverse trabecular bone loss in ovariectomized osteopenic rats. ${ }^{87}$

\section{Implications for human therapy}

Regardless of their sensitivity to alcohol, there has been a rise in alcohol dependence and abuse among the populations of $A L D H 2 * 2$ carriers in East Asian countries and their descendants. ${ }^{88,89}$ In Japan, $26 \%$ of heavy drinkers are $A L D H 2 * 2$ heterozygotes, ${ }^{90}$ and $58 \%$ of Asian American college students with an inactive $A L D H 2 * 2$ allele are regular drinkers. ${ }^{91}$ This presents a large population with a highly increased risk of chronic disorders such as upper aerodigestive tract cancer and, without intervention, an emerging public health crisis. ${ }^{2,3,92}$ Abstaining from alcohol is currently the only treatment for reducing the high risk of upper aerodigestive tract cancer and osteoporosis associated with ALDH2 deficiency. Our data support the concept that AAV-mediated gene therapy presents a possible effective preventative therapy for the chronic disorders associated with chronic ethanol consumption in individuals with the ALDH2 deficiency state.

Although AAVrh.10hALDH2 may prevent the deleterious physiological effects of chronic alcohol consumption for individuals with the $A L D H 2 * 2$ allele, the therapy may be limited in addressing the underlying reward-addiction cycle relevant for alcoholism. The $A L D H 2 * 2$ allele is generally associated with a lower risk of alcoholism because of the immediate deleterious physiological effects of alcohol consumption. ${ }^{93}$ However, $A L D H 2 * 2$ alcoholics become tolerant of these physiological effects with continued alcohol consumption. ${ }^{94}$ Studies of Chinese and Korean alcoholics found that heterozygous $A L D H 2 * 2$ individuals scored significantly higher on the positive alcohol expectancies scale and lower on the negative alcohol expectancies scale than individuals with a functional ALDH2. ${ }^{95,96}$ In animal studies, acetaldehyde demonstrates several properties that are similar to addictive drugs, including activation of dopamine receptors, locomotor stimulation, and selfadministration. ${ }^{97-103}$ Interestingly, administration of a lentiviral vector encoding $A L D H 2$ into the brain ventral tegmental area of rats reduced ethanol consumption and binge drinking in rats bred for alcohol preference. ${ }^{104} \mathrm{In}$ this context, AAVrh.10hALDH2 reduces systemic acetaldehyde levels with drinking alcohol, and thus may help reduce addictive behaviors in addition to protecting against the serious physiological effects of chronic alcohol consumption in $A L D H 2 * 2$ individuals.

There is also epidemiological evidence that ALDH2 deficiency is implicated in several other diseases including neurological disorders, diabetes, cardiac ischemia, stroke, hepatocellular carcinoma, chronic obstructive pulmonary disease, severity of Fanconi anemia, and dermatitis. ${ }^{2,3}$ ALDH2 not only converts acetaldehyde to acetate in the ethanol metabolism pathway, but also metabolizes numerous other aldehydes such as 4-HNE and MDA, by products of oxidative stress, and acrolein, an environmental aldehyde found in tobacco smoke, car exhaust, and other pollutants. ${ }^{2,105}$ In this study, significantly more MDA was observed in the liver

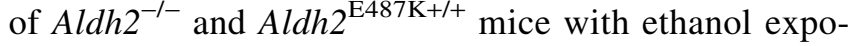
sure, which was prevented by AAVrh.10hALDH2 therapy. These aldehydes induce cytotoxicity because of their ability to spread through cell membranes and produce adducts with DNA, proteins, and lipids that disrupt their function. ${ }^{106-108}$ Without a functioning ALDH2 enzyme, the clearance mechanisms available to protect cells and tissue from aldehyde-mediated damage are limited.

In summary, the data show that AAVrh.10hALDH2 gene therapy prevents chronic ethanol consumptioninduced disease-related phenotypes in the two mouse models of ALDH2 deficiency. The overall effects of ALDH2 deficiency on human health, specifically the marked increase risk for cancer and osteoporosis, support the concept of developing AAVrh.10hALDH2 as a preventative therapy in high-risk ALDH2-deficient individuals. 


\section{ACKNOWLEDGMENTS}

We thank S. Cronin, A. Camilleri, S. Nag, and F. Hart for assistance with these studies; J. Fernandez and H. Molina at the Proteomics Resource Center at Rockefeller University for assisting with the LC/MS acetaldehyde and DNA adducts assays; S. Rafii for the use of the ADVIA hematology system; and N. Mohamed for editorial assistance.

\section{AUTHOR DISCLOSURE}

R.G.C. has equity in LEXEO and R.G.C. and O.E.P. are participants in a patent disclosure regarding gene therapy for ALDH2 deficiency.

\section{FUNDING INFORMATION}

These studies were supported, in part, by National Institute of Health R41 AA027730 01 to LEXEO
Therapeutics and, in part, by the Department of Genetic Medicine, Y.M. was supported, in part, by a scholarship from the Uehara Memorial Foundation (Japan), and OEP was supported, in part, by a Parker B. Francis Fellowship. M.B.G. holds award DP5OD021351 from the Office of the Director of the NIH, a Career Award for Medical Scientists from the Burroughs Welcome Foundation, and a Pershing Square Sohn Prize for Young Investigators in Cancer Research. Research reported in this publication was supported by the NIAA/ NIH. The content is solely the responsibility of the authors and does not necessarily represent the official views of the NIH.

\section{SUPPLEMENTARY MATERIAL}

Supplementary Data

\section{REFERENCES}

1. Brooks PJ, Enoch MA, Goldman D, et al. The alcohol flushing response: an unrecognized risk factor for esophageal cancer from alcohol consumption. PLoS Med 2009;6:e50.

2. Chen $\mathrm{CH}$, Ferreira JC, Gross ER, et al. Targeting aldehyde dehydrogenase 2: new therapeutic opportunities. Physiol Rev 2014;94:1-34.

3. Gross ER, Zambelli VO, Small BA, et al. A personalized medicine approach for Asian Americans with the aldehyde dehydrogenase $2^{*} 2$ variant. Annu Rev Pharmacol Toxicol 2015;55:107-127.

4. Yoshida A, Rzhetsky A, Hsu LC, et al. Human aldehyde dehydrogenase gene family. Eur $\mathrm{J}$ Biochem 1998;251:549-557.

5. Koivisto T, Salaspuro M. Aldehyde dehydrogenases of the rat colon: comparison with other tissues of the alimentary tract and the liver. Alcohol Clin Exp Res 1996;20:551-555.

6. Stewart MJ, Malek K, Crabb DW. Distribution of messenger RNAs for aldehyde dehydrogenase 1 , aldehyde dehydrogenase 2, and aldehyde dehydrogenase 5 in human tissues. J Investig Med 1996:44:42-46.

7. Klyosov AA, Rashkovetsky LG, Tahir MK, et al. Possible role of liver cytosolic and mitochondrial aldehyde dehydrogenases in acetaldehyde metabolism. Biochemistry 1996;35:4445-4456.

8. Chen CH, Sun L, Mochly-Rosen D. Mitochondrial aldehyde dehydrogenase and cardiac diseases. Cardiovasc Res 2010;88:51-57.

9. Jin S, Chen J, Chen L, et al. ALDH2(E487K) mutation increases protein turnover and promotes murine hepatocarcinogenesis. Proc Natl Acad Sci U S A 2015;112:9088-9093.

10. Weiner H, Wei B, Zhou J. Subunit communication in tetrameric class 2 human liver aldehyde dehydrogenase as the basis for half-of-the-site reactivity and the dominance of the oriental subunit in a heterotetramer. Chem Biol Interact 2001;130:47-56

11. Larson HN, Zhou J, Chen Z, et al. Structural and functional consequences of coenzyme binding to the inactive Asian variant of mitochondrial aldehyde dehydrogenase: roles of residues 475 and 487. J Biol Chem 2007;282:12940-12950.

12. Kitagawa K, Kawamoto $\mathrm{T}$, Kunugita $\mathrm{N}$, et al. Aldehyde dehydrogenase (ALDH) 2 associates with oxidation of methoxyacetaldehyde; in vitro analysis with liver subcellular fraction derived from human and Aldh2 gene targeting mouse. FEBS Lett 2000;476:306-311.

13. Lai CL, Yao CT, Chau GY, et al. Dominance of the inactive Asian variant over activity and protein contents of mitochondrial aldehyde dehydrogenase 2 in human liver. Alcohol Clin Exp Res 2014;38:44-50.

14. Luo HR, Wu GS, Pakstis AJ, et al. Origin and dispersal of atypical aldehyde dehydrogenase ALDH2487Lys. Gene 2009;435:96-103.

15. Peng GS, Chen YC, Tsao TP, et al. Pharmacokinetic and pharmacodynamic basis for partial protection against alcoholism in Asians, heterozygous for the variant ALDH2*2 gene allele. Pharmacogenet Genomics 2007;17:845-855

16. Yokoyama A, Omori T, Yokoyama T, et al. Risk of metachronous squamous cell carcinoma in the upper aerodigestive tract of Japanese alcoholic men with esophageal squamous cell carcinoma: a long-term endoscopic follow-up study. Cancer Sci 2008;99:1164-1171.

17. Yokoyama A, Omori T, Yokoyama T, et al. Risk of squamous cell carcinoma of the upper aerodigestive tract in cancer-free alcoholic Japanese men: an endoscopic follow-up study. Cancer Epidemiol Biomarkers Prev 2006;15:2209-2215.
18. Fujiwara S, Kasagi F, Yamada M, et al. Risk factors for hip fracture in a Japanese cohort. J Bone Miner Res 1997;12:998-1004.

19. Giuliani N, Girasole G, Vescovi PP, et al. Ethanol and acetaldehyde inhibit the formation of early osteoblast progenitors in murine and human bone marrow cultures. Alcohol Clin Exp Res 1999;23:381-385.

20. Hoshi H, Hao W, Fujita Y, et al. Aldehyde-stress resulting from Aldh2 mutation promotes osteoporosis due to impaired osteoblastogenesis. J Bone Miner Res 2012;27:2015-2023.

21. Kanis JA, Johansson $H$, Johnell 0 , et al. Alcohol intake as a risk factor for fracture. Osteoporos Int 2005;16:737-742.

22. Kanis JA, Johnell O, Oden A, et al. FRAX and the assessment of fracture probability in men and women from the UK. Osteoporos Int 2008;19:385-397.

23. Takeshima K, Nishiwaki $Y$, Suda $Y$, et al. A missense single nucleotide polymorphism in the ALDH2 gene, rs671, is associated with hip fracture. Sci Rep 2017;7:428.

24. Yamaguchi J, Hasegawa Y, Kawasaki M, et al ALDH2 polymorphisms and bone mineral density in an elderly Japanese population. Osteoporos Int 2006;17:908-913.

25. Zambelli VO, Gross ER, Chen CH, et al. Aldehyde dehydrogenase-2 regulates nociception in rodent models of acute inflammatory pain. Sci Transl Med 2014;6:251ra118.

26. Matsuda T, Matsumoto A, Uchida M, et al Increased formation of hepatic N2-ethylidene-2' deoxyguanosine DNA adducts in aldehyde dehydrogenase 2-knockout mice treated with ethanol. Carcinogenesis 2007;28:2363-2366.

27. Amanuma Y, Ohashi S, Itatani Y, et al. Protective role of ALDH2 against acetaldehyde-derived 
DNA damage in oesophageal squamous epithelium. Sci Rep 2015;5:14142.

28. Isse T, Oyama T, Matsuno $K$, et al. Aldehyde dehydrogenase 2 activity affects symptoms produced by an intraperitoneal acetaldehyde injection, but not acetaldehyde lethality. J Toxicol Sci 2005;30:315-328.

29. Oyama T, Isse T, Ogawa M, et al. Susceptibility to inhalation toxicity of acetaldehyde in Aldh2 knockout mice. Front Biosci 2007;12:1927-1934.

30. Matsumura Y, Stiles KM, Reid J, et al. Gene therapy correction of aldehyde dehydrogenase 2 deficiency. Mol Ther Methods Clin Dev 2019;15: 72-82.

31. World Healht Organization. Global status report on alcohol and health 2018. https://apps .who.int/iris/rest/bitstreams/1151838/retrieve (last accessed September 19, 2019).

32. De BP, Heguy A, Hackett NR, et al. High levels of persistent expression of alpha1-antitrypsin mediated by the nonhuman primate serotype rh. 10 adeno-associated virus despite preexisting immunity to common human adeno-associated viruses. Mol Ther 2006;13:67-76.

33. De BP, Hackett NR, Crystal RG, et al. Rapid/ sustained anti-anthrax passive immunity mediated by co-administration of Ad/AAV. Mol Ther 2008;16:203-209.

34. Guan X, Rubin E, Anni H. An optimized method for the measurement of acetaldehyde by highperformance liquid chromatography. Alcohol Clin Exp Res 2012;36:398-405.

35. Marnett LJ. Lipid peroxidation-DNA damage by malondialdehyde. Mutat Res 1999;424:83-95.

36. Bartsch H, Nair J. Accumulation of lipid peroxidation-derived DNA lesions: potential lead markers for chemoprevention of inflammationdriven malignancies. Mutat Res 2005;591:34-44.

37. Matsumoto A, Vasiliou V, Kawamoto T, et al. Ethanol reduces lifespan, body weight, and serum alanine aminotransferase level of aldehyde dehydrogenase 2 knockout mouse. Alcohol Clin Exp Res 2014;38:1883-1893.

38. Matsumoto A, Ito S, Wakamatsu K, et al. Ethanol induces skin hyperpigmentation in mice with aldehyde dehydrogenase 2 deficiency. Chem Biol Interact 2019;302:61-66.

39. Balbo S, Hashibe M, Gundy S, et al. N2ethyldeoxyguanosine as a potential biomarker for assessing effects of alcohol consumption on DNA. Cancer Epidemiol Biomarkers Prev 2008; 17:3026-3032.

40. Kuo LJ, Yang LX. Gamma-H2AX-a novel biomarker for DNA double-strand breaks. In Vivo 2008;22:305-309.

41. Shimizu Y, Sakai A, Menuki K, et al. Reduced bone formation in alcohol-induced osteopenia is associated with elevated p21 expression in bone marrow cells in aldehyde dehydrogenase 2disrupted mice. Bone 2011:48:1075-1086.
42. Greenblatt MB, Shim JH, Zou W, et al. The p38 MAPK pathway is essential for skeletogenesis and bone homeostasis in mice. J Clin Invest 2010;120:2457-2473.

43. Campbell GM, Tiwari S, Grundmann F, et al. Three-dimensional image registration improves the long-term precision of in vivo microcomputed tomographic measurements in anabolic and catabolic mouse models. Calcif Tissue Int 2014;94:282-292.

44. Lee $\mathrm{CH}, \mathrm{Wu} D C$, Wu IC, et al. Genetic modulation of $\mathrm{ADH} 1 \mathrm{~B}$ and $\mathrm{ALDH} 2$ polymorphisms with regard to alcohol and tobacco consumption for younger aged esophageal squamous cell carcinoma diagnosis. Int J Cancer 2009;125:11341142.

45. Morita M, Kumashiro R, Kubo N, et al. Alcohol drinking, cigarette smoking, and the development of squamous cell carcinoma of the esophagus: epidemiology, clinical findings, and prevention. Int J Clin Oncol 2010;15:126-134.

46. Oyama $T$, Kim YD, Isse $T$, et al. A pilot study on subacute ethanol treatment of ALDH2 KO mice. J Toxicol Sci 2007;32:421-428.

47. Kato N, Takeuchi F, Tabara Y, et al. Metaanalysis of genome-wide association studies identifies common variants associated with blood pressure variation in east Asians. Nat Genet 2011;43:531-538.

48. Takeuchi F, Isono M, Nabika T, et al. Confirmation of ALDH2 as a Major locus of drinking behavior and of its variants regulating multiple metabolic phenotypes in a Japanese population. Circ J 2011;75:911-918.

49. Woutersen RA, Appelman LM, Van GarderenHoetmer A, et al. Inhalation toxicity of acetaldehyde in rats. III. Carcinogenicity study. Toxicology 1986;41:213-231.

50. Savage D, Lindenbaum J. Anemia in alcoholics. Medicine (Baltimore) 1986;65:322-338.

51. Yokoyama A, Brooks PJ, Yokoyama T, et al. Recovery from anemia and leukocytopenia after abstinence in Japanese alcoholic men and their genetic polymorphisms of alcohol dehydrogenase$1 \mathrm{~B}$ and aldehyde dehydrogenase-2. Jpn J Clin Oncol 2017;47:306-312.

52. Yokoyama M, Yokoyama A, Yokoyama T, et al. Mean corpuscular volume and the aldehyde dehydrogenase-2 genotype in male Japanese workers. Alcohol Clin Exp Res 2003;27:13951401.

53. Garaycoechea JI, Crossan GP, Langevin F, et al. Genotoxic consequences of endogenous aldehydes on mouse haematopoietic stem cell function. Nature 2012;489:571-575.

54. Garaycoechea JI, Crossan GP, Langevin F, et al. Alcohol and endogenous aldehydes damage chromosomes and mutate stem cells. Nature 2018;553:171-177.

55. Hira A, Yabe H, Yoshida K, et al. Variant ALDH2 is associated with accelerated progression of bone marrow failure in Japanese Fanconi anemia patients. Blood 2013;122:3206-3209.

56. Van Wassenhove LD, Mochly-Rosen D, Weinberg KI. Aldehyde dehydrogenase 2 in aplastic anemia, Fanconi anemia and hematopoietic stem cells. Mol Genet Metab 2016;119:28-36.

57. Kamino K, Nagasaka K, Imagawa M, et al. Deficiency in mitochondrial aldehyde dehydrogenase increases the risk for late-onset Alzheimer's disease in the Japanese population. Biochem Biophys Res Commun 2000;273:192-196.

58. Wang B, Wang J, Zhou S, et al. The association of mitochondrial aldehyde dehydrogenase gene (ALDH2) polymorphism with susceptibility to late-onset Alzheimer's disease in Chinese. J Neurol Sci 2008;268:172-175.

59. Zhao CC, Cai HB, Wang H, et al. Role of ADH2 and ALDH2 gene polymorphisms in the development of Parkinson's disease in a Chinese population. Genet Mol Res 2016;15. DOI: 10.4238/gmr.15038606.

60. Yu R-L, Tan C-H, Lu Y-C, et al. Aldehyde dehydrogenase 2 is associated with cognitive functions in patients with Parkinson's disease. Sci Rep 2016;6:30424.

61. Wey MC, Fernandez E, Martinez PA, et al. Neurodegeneration and motor dysfunction in mice lacking cytosolic and mitochondrial aldehyde dehydrogenases: implications for Parkinson's disease. PLoS One 2012;7:e31522.

62. Liu SW, Lien MH, Fenske NA. The effects of alcohol and drug abuse on the skin. Clin Dermatol 2010;28:391-399.

63. Yokoyama A, Omori T, Yokoyama T, et al. Esophageal melanosis, an endoscopic finding associated with squamous cell neoplasms of the upper aerodigestive tract, and inactive aldehyde dehydrogenase-2 in alcoholic Japanese men. J Gastroenterol 2005:40:676-684.

64. Hirohashi K, Ohashi S, Amanuma Y, et al. Protective effects of Alda-1, an ALDH2 activator, on alcohol-derived DNA damage in the esophagus of human ALDH2*2 (Glu504Lys) knock-in mice. Carcinogenesis 2019 [Epub ahead of print]; DOI: 10.1093/carcin/bgz091.

65. Tetreault MP. Esophageal cancer: Insights from mouse models. Cancer Growth Metastasis 2015; 8:37-46.

66. Yukawa Y, Ohashi S, Amanuma Y, et al. Impairment of aldehyde dehydrogenase 2 increases accumulation of acetaldehyde-derived DNA damage in the esophagus after ethanol ingestion. Am J Cancer Res 2014;4:279-284.

67. Soffritti M, Belpoggi F, Lambertin L, et al. Results of long-term experimental studies on the carcinogenicity of formaldehyde and acetaldehyde in rats. Ann N Y Acad Sci 2002;982:87-105.

68. Internatioanl Agency for Research on Cancer, World Health Organization. IARC strengthens its findings on several carcinogenic peronal habits and housefhold exposures. 2009. https:// 
www.iarc.fr/wp-content/uploads/2018/07/pr196_ E.pdf (last accessed September 19, 2019).

69. Secretan B, Straif K, Baan R, et al. A review of human carcinogens - part E: tobacco, areca nut, alcohol, coal smoke, and salted fish. Lancet Oncol 2009;10:1033-1034.

70. Kotova N, Vare D, Schultz N, et al. Genotoxicity of alcohol is linked to DNA replicationassociated damage and homologous recombination repair. Carcinogenesis 2013;34:325-330.

71. Seitz HK, Meier P. The role of acetaldehyde in upper digestive tract cancer in alcoholics. Transl Res 2007;149:293-297.

72. Toh Y, Oki E, Ohgaki K, et al. Alcohol drinking, cigarette smoking, and the development of squamous cell carcinoma of the esophagus: molecular mechanisms of carcinogenesis. Int $\mathrm{J}$ Clin Oncol 2010;15:135-144.

73. Garcia CC, Angeli JP, Freitas FP, et al. [13C2]Acetaldehyde promotes unequivocal formation of 1,N2-propano-2'-deoxyguanosine in human cells. J Am Chem Soc 2011;133:9140-9143.

74. Vaca CE, Fang JL, Schweda EK. Studies of the reaction of acetaldehyde with deoxynucleosides. Chem Biol Interact 1995;98:51-67.

75. Matsuda T, Yabushita H, Kanaly RA, et al. Increased DNA damage in ALDH2-deficient alcoholics. Chem Res Toxicol 2006;19:1374-1378.

76. Cauley JA. Public health impact of osteoporosis. J Gerontol A Biol Sci Med Sci 2013;68:1243-1251.

77. Borhan S, Papaioannou A, Gajic-Veljanoski O, et al. incident fragility fractures have a long-term negative impact on health-related quality of life of older people: the Canadian Multicentre Osteoporosis Study. J Bone Miner Res 2019;34: 838-848.

78. Nakamura Y, Amamoto K, Tamaki S, et al. Genetic variation in aldehyde dehydrogenase 2 and the effect of alcohol consumption on cholesterol levels. Atherosclerosis 2002;164:171-177.

79. Yokoyama A, Yokoyama T, Matsui T, et al. Trends in gastrectomy and ADH1B and ALDH2 genotypes in Japanese alcoholic men and their gene-gastrectomy, gene-gene and gene-age interactions for risk of alcoholism. Alcohol Alcohol 2013;48:146-152.

80. United Nations, Department of Economic and Social Affairs/Population Division World Population Prospects 2019. https://population.un.org/ wpp/Download/Standard/Population/ (last accessed September 19, 2019).

81. Hurley MM, Martin DL, Kream BE, et al. Effects of ethanol and acetaldehyde on collagen synthesis, prostaglandin release and resorption of fetal rat bone in organ culture. Bone 1990;11:47-51.

82. Friday KE, Howard GA. Ethanol inhibits human bone cell proliferation and function in vitro. Metabolism 1991;40:562-565.

83. Balbo S, Juanes RC, Khariwala $S$, et al. Increased levels of the acetaldehyde-derived DNA adduct $\mathrm{N}$ 2-ethyldeoxyguanosine in oral mucosa DNA from Rhesus monkeys exposed to alcohol. Mutagenesis 2016;31:553-558.

84. Vakevainen S, Tillonen J, Agarwal DP, et al. High salivary acetaldehyde after a moderate dose of alcohol in ALDH2-deficient subjects: strong evidence for the local carcinogenic action of acetaldehyde. Alcohol Clin Exp Res 2000;24: 873-877.

85. Vakevainen S, Tillonen J, Salaspuro M. 4Methylpyrazole decreases salivary acetaldehyde levels in aldh2-deficient subjects but not in subjects with normal aldh2. Alcohol Clin Exp Res 2001;25:829-834.

86. Helminen A, Vakevainen S, Salaspuro M. ALDH2 genotype has no effect on salivary acetaldehyde without the presence of ethanol in the systemic circulation. PLoS One 2013:8:e74418.

87. Mittal M, Pal S, China SP, et al. Pharmacological activation of aldehyde dehydrogenase 2 promotes osteoblast differentiation via bone morphogenetic protein-2 and induces bone anabolic effect. Toxicol Appl Pharmacol 2017;316:63-73.

88. Higuchi S, Matsushita S, Imazeki H, et al. Aldehyde dehydrogenase genotypes in Japanese alcoholics. Lancet 1994;343:741-742.

89. Iwamoto DK, Kaya A, Grivel M, et al. Underresearched demographics: heavy episodic drinking and alcohol-related problems among Asian Americans. Alcohol Res 2016;38:17-25.

90. Yokoyama A, Kato H, Yokoyama T, et al. Genetic polymorphisms of alcohol and aldehyde dehydrogenases and glutathione S-transferase M1 and drinking, smoking, and diet in Japanese men with esophageal squamous cell carcinoma. Carcinogenesis 2002;23:1851-1859.

91. Wall TL, Shea SH, Chan KK, et al. A genetic association with the development of alcohol and other substance use behavior in Asian Americans. J Abnorm Psychol 2001;110:173-178.

92. Chang JS, Hsiao JR, Chen CH. ALDH2 polymorphism and alcohol-related cancers in Asians: a public health perspective. J Biomed Sci 2017; 24:19.

93. Edenberg HJ. The genetics of alcohol metabolism: role of alcohol dehydrogenase and aldehyde dehydrogenase variants. Alcohol Res Health 2007:30:5-13

94. Chen YC, Peng GS, Tsao TP, et al. Pharmacokinetic and pharmacodynamic basis for overcoming acetaldehyde-induced adverse reaction in Asian alcoholics, heterozygous for the variant $\mathrm{ALDH}_{2}{ }^{*} 2$ gene allele. Pharmacogenet Genomics 2009:19:588-599.

95. Hahn CY, Huang SY, Ko HC, et al. Acetaldehyde involvement in positive and negative alcohol expectancies in Han Chinese persons with alcoholism. Arch Gen Psychiatry 2006;63: 817-823.

96. Mahoney B, Graham D, Cottrell D, et al. Punishment sensitivity and tension reduction: Ex- ploring the potential influence of genetics on South Korean alcohol consumption. Cogent Psychol 2016;3:1149264.

97. Amit Z, Smith BR. A multi-dimensional examination of the positive reinforcing properties of acetaldehyde. Alcohol 1985;2:367-370.

98. Myers WD, Ng KT, Singer G, et al. Dopamine and salsolinol levels in rat hypothalami and striatum after schedule-induced self-injection (SISI) of ethanol and acetaldehyde. Brain Res 1985;358:122-128.

99. Rodd-Henricks ZA, Melendez RI, Zaffaroni A, et al. The reinforcing effects of acetaldehyde in the posterior ventral tegmental area of alcoholpreferring rats. Pharmacol Biochem Behav 2002; 72:55-64.

100. Correa M, Arizzi MN, Betz A, et al. Open field locomotor effects in rats after intraventricular injections of ethanol and the ethanol metabolites acetaldehyde and acetate. Brain Res Bull 2003; 62:197-202.

101. Quertemont E, Tambour S, Bernaerts $P$, et al Behavioral characterization of acetaldehyde in C57BL/6J mice: locomotor, hypnotic, anxiolytic and amnesic effects. Psychopharmacology (Berl) 2004;177:84-92

102. Quertemont E, Tambour S, Tirelli E. The role of acetaldehyde in the neurobehavioral effects of ethanol: a comprehensive review of animal studies. Prog Neurobiol 2005;75:247-274.

103. Peana AT, Porcheddu V, Bennardini F, et al. Role of ethanol-derived acetaldehyde in operant oral self-administration of ethanol in rats. Psychopharmacology (Berl) 2015;232:4269-4276.

104. Karahanian E, Rivera-Meza M, Tampier L, et al. Long-term inhibition of ethanol intake by the administration of an aldehyde dehydrogenase-2 (ALDH2)-coding lentiviral vector into the ventral tegmental area of rats. Addict Biol 2015;20:336344.

105. Yoval-Sanchez B, Rodriguez-Zavala JS. Differences in susceptibility to inactivation of human aldehyde dehydrogenases by lipid peroxidation byproducts. Chem Res Toxicol 2012;25:722729.

106. Esterbauer H, Schaur RJ, Zollner H. Chemistry and biochemistry of 4-hydroxynonenal, malonaldehyde and related aldehydes. Free Radic Biol Med 1991;11:81-128

107. Petersen DR, Doorn JA. Reactions of 4hydroxynonenal with proteins and cellular targets. Free Radic Biol Med 2004;37:937-945.

108. Tang MS, Wang HT, Hu Y, et al. Acrolein induced DNA damage, mutagenicity and effect on DNA repair. Mol Nutr Food Res 2011;55:1291-1300.

Received for publication September 21, 2019; accepted after revision November 9, 2019.

Published online: December 4, 2019. 